\title{
Application of Calixarenes as Macrocyclic Ligands for Uranium(VI): A Review
}

\author{
Katarzyna Kiegiel, Lukasz Steczek, and Grazyna Zakrzewska-Trznadel \\ Centre for Radiochemistry and Nuclear Chemistry, Institute of Nuclear Chemistry and Technology, Dorodna 16, 03-195 Warsaw, Poland \\ Correspondence should be addressed to Katarzyna Kiegiel; k.kiegiel@ichtj.waw.pl
}

Received 22 June 2012; Revised 15 September 2012; Accepted 8 October 2012

Academic Editor: Satoru Tsushima

Copyright ( 2013 Katarzyna Kiegiel et al. This is an open access article distributed under the Creative Commons Attribution License, which permits unrestricted use, distribution, and reproduction in any medium, provided the original work is properly cited.

\begin{abstract}
Calixarenes represent a well-known family of macrocyclic molecules with broad range of potential applications in chemical, analytical, and engineering materials fields. This paper covers the use of calixarenes as complexing agents for uranium(VI). The high effectiveness of calix[6] arenes in comparison to other calixarenes in uranium(VI) separation process is also presented. Processes such as liquid-liquid extraction (LLE), liquid membrane (LM) separation, and ion exchange are considered as potential fields for application of calixarenes as useful agents for binding $\mathrm{UO}_{2}{ }^{2+}$ for effective separation from aqueous solutions containing other metal components.
\end{abstract}

\section{Introduction}

In the last years an increasing interest in calixarenes as potential complexing agents for metals, among them actinides, is observed. It is supported by several reviews [1-3]. The present paper focuses on application of calixarenes for separation of uranium(VI) from competing metal ions in aqueous solutions.

Uranium plays an important role in generation of nuclear power. The selective isolation of uranium is of particular interest in the context of both energy resources and treatment of nuclear wastes. As a key element for production of the fuel for nuclear reactors, uranium, the more common element in the Earth's crust occurring in rocks, soil, and river and ocean waters [4], has to be extracted from the raw material in complex hydrometallurgical processes involving many separation steps. Processes such as acidic leaching, liquidliquid extraction, or ion exchange are applied to obtain pure triuranium octaoxide $\left(\mathrm{U}_{3} \mathrm{O}_{8}\right)$ from uranium ore. Since in most of uranium minerals uranium is accompanied by other heavy metals, postleaching solutions usually contain a mixture of different metallic ions that should be separated from $\mathrm{UO}_{2}{ }^{2+}$, the uranyl ion that forms complexes with various organic chelating agents. The separation can be achieved by using of extracting agents that exhibit high specificity towards $\mathrm{UO}_{2}{ }^{2+}$ and allowing selective uranium recovery.

Uranium(VI) has unique characteristics, namely, the extreme stability of the triatomic uranyl ion $\mathrm{OUO}^{2+}$. This ion possesses very stable uranium(VI)-oxygen double bonds, leaving the oxygen atoms largely unreactive [5]. In crystalline structures, $\mathrm{UO}_{2}{ }^{2+}$ is linear and is capable of forming complexes of coordinative bonds with host molecules containing five or six ligand groups, primarily oxygen atoms [6]. This suggests that a macrocyclic host molecule having a nearly coplanar arrangement of either five or six ligand groups would act as a specific ligand for $\mathrm{UO}_{2}{ }^{2+}$ (i.e., as an uranophile).

In order to design a ligand that can selectively extract $\mathrm{UO}_{2}{ }^{2+}$, one has to overcome a difficult problem, that is, the ligand must discriminate strictly between $\mathrm{UO}_{2}{ }^{2+}$ and other metal ions present in great excess in water or waste solution. Over the last three decades, a variety of studies have targeted molecular design and implementation of various polydentate compounds that serve effectively as uranium(VI) extracting agents, for example, a macrocyclic hexaketone, macrocyclic hexacarboxylic acid, and tridithiocarbamate synthesized by Tabushi et al. [7-9]. Shinkai and coworkers [10] applied 


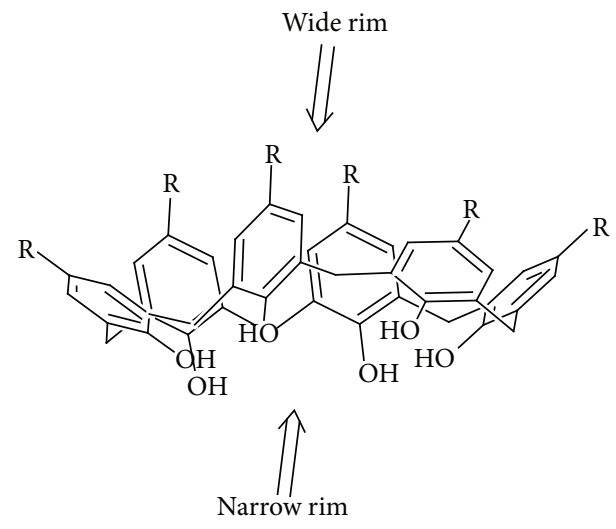

FiguRE 1: Illustration of the structure of calixarenes.

calixarenes for $\mathrm{UO}_{2}{ }^{2+}$ complexation with efficient results in terms of stability and selectivity. The increasing interest in these macrocycles is not only due to their easy synthesis through well-established and simple methodologies [11], but also due to the possibility of shaping their basket through functionalization at the lower (narrow) or at upper (wide) rims (Figure 1).

Calixarenes are formed by paraphenolic units linked by methylene bridges ortho to $\mathrm{OH}$ functions. In addition, they can be easily functionalized to be more specific. The OR groups (chelating groups) on the lower rim are usually chosen for their affinity and selectivity towards a specific molecule or ion. On the other hand, the groups in paraposition on the upper rim can give hydrophilic or hydrophobic character to the molecule. These groups can also rigidify the conformation of calix $[n]$ arene.

The extraction study of lanthanides and actinides showed that the calixarenes bearing ligands including $\mathrm{P}=\mathrm{O}$ groups were more efficient than TBP (tributyl phosphate), TOPO (trioctylphosphine oxide), and CMPO (carbamoyl phosphonate) $[12,13]$. The ligand concentration necessary to reach a given extraction yield was 10 to 100 times lower with the calixarenes than with the classical extractants.

Very interesting results were obtained in the study of toxicity of calixarenes [14]. The calix[6] arenes and calix[8] arenes functionalized with sulfonate group had the same level of toxicity as glucose. On the other hand, derivatives of $p$ sulfonato-calix[4] arenes showed slight toxicity, in contrast to calix[4] arene phosphonic acid derivatives which exhibited no effect on the cell growth of human fibroblast. It is worthy to remind that derivatives of $p$-sulfonato calix[6] arene and calix[8] arene analogs were investigated in radiotherapy [15]. Complexation studies of ${ }^{230} \mathrm{U}$ with these calixarenes showed that in vivo application of such compounds is not possible. The complexation of uranium(VI) was efficient, but serum proteins and carbonate led to the destruction of the desired complexes.

The ligands that can be used in chemical process of radioactive waste treatment should be resistant to chemical and radiolytic conditions. Although calixarenes were well examined for their chemical stability under acidic and basic conditions, their behavior under irradiation conditions is still under investigation. It was found that after the exposure to the gamma radiation the ligands could change their properties. Mariani et al. [16] studied a derivative of calix[6]arenes. They observed that an absorbed dose above $100 \mathrm{kGy}$ in the presence of air decreased the distribution coefficient for ${ }^{241} \mathrm{Am}$ and ${ }^{152} \mathrm{Eu}$ without significant influence on the selectivity in comparison to nonirradiated ligands. However, an absorbed dose up to $55 \mathrm{kGy}$ in the presence of air caused an increase of the distribution coefficient for both metals. The same absorbed dose in the presence of nitrogen caused a decrease of the distribution coefficient. These results indicated how important the influence of oxidizing environment on radiolysis is.

\section{Speciation of Uranium(VI) in Water}

The speciation of uranium(VI) in aqueous solution is very important to understand the mechanism of extraction and to choose the appropriate extraction system. In aqueous solution, uranium(VI) exists as a linear $\mathrm{UO}_{2}{ }^{2+}$, and it forms stable complexes with both organic and inorganic ligands [17, 18]. Simulations [19, 20], calculations [21], and experiments $[22,23]$ suggest that in water, $\mathrm{UO}_{2}{ }^{2+}$ is coordinated to five water molecules. The hydrolysis of uranium(VI) has been investigated by different techniques, for example, Raman spectroscopy [24], calorimetry, and potentiometry [25]. Moll et al. [26] investigated the structure of $\mathrm{UO}_{2}{ }^{2+}$ as a function of $\mathrm{pH}$ with the aid of $\mathrm{U} \mathrm{L}_{\mathrm{III}}$-edge EXAFS (extended $\mathrm{X}$ ray absorption fine structure) spectroscopy. $\mathrm{UO}_{2}{ }^{2+}$ forms strong complexes with $\mathrm{OH}^{-}$. In slightly acidic solutions ( $\mathrm{pH} 3$ to 4 ), there are two dominated polynuclear complexes: $\left(\mathrm{UO}_{2}\right)_{2}(\mathrm{OH})_{2}{ }^{2+}$ and $\left(\mathrm{UO}_{2}\right)_{3}(\mathrm{OH})_{5}{ }^{+}$. In the $\mathrm{pH}$ region between $6-11$, the uranium(VI) speciation is dominated by the precipitation of schoepite phases $\mathrm{UO}_{2}(\mathrm{OH})_{2} \cdot \mathrm{H}_{2} \mathrm{O}$. In the presence of carbonate or atmospheric carbon dioxide, in the basic $\mathrm{pH}$ region uranyl-carbonate complexes: $\mathrm{UO}_{2} \mathrm{CO}_{3}$, $\mathrm{UO}_{2}\left(\mathrm{CO}_{3}\right)_{2}{ }^{2-}$, and $\mathrm{UO}_{2}\left(\mathrm{CO}_{3}\right)_{3}{ }^{4-}$ are formed [27].

The complexes of uranium(VI) with $\mathrm{NO}_{3}{ }^{-}$are the most fundamental species in the PUREX process (plutonium and uranium recovery by extraction), which is a liquid-liquid extraction method used to reprocess spent nuclear fuel. This is the most developed and widely used process in commercial reprocessing plants. Most of the unit operations in the PUREX reprocessing process are carried out in aqueous nitrate media. In aqueous nitrate the water molecules in the first hydration shell are replaced by the bidentate species $\mathrm{NO}_{3}{ }^{-}$as a function of increasing $\mathrm{NO}_{3}{ }^{-}$concentration at low $\mathrm{pH}$ [28]. With increasing $\mathrm{HNO}_{3}$ concentration, coordination numbers $(\mathrm{CN})$ increase from 5 to 6 . The $\mathrm{U}(\mathrm{VI})-\mathrm{NO}_{3}{ }^{-}$ complexation system in $\mathrm{HNO}_{3}$ undergoes the formation of a 5 -fold bidentate coordination mononitrato complex, $\left[\mathrm{U}^{\mathrm{VI}} \mathrm{O}_{2}\left(\mathrm{H}_{2} \mathrm{O}\right)_{3}\left(\eta_{2}-\mathrm{NO}_{3}\right)\right]^{+}$, and a 6 -fold bidentate coordinated dinitrato complex, $\left[\mathrm{U}^{\mathrm{VI}} \mathrm{O}_{2}\left(\mathrm{H}_{2} \mathrm{O}\right)_{2}\left(\eta_{2}-\mathrm{NO}_{3}\right)_{2}\right]^{0}$. The complexation of uranium(VI) by $\mathrm{NO}_{3}{ }^{-}$terminates with the formation of the trinitrate species, $\left[\mathrm{U}^{\mathrm{VI}} \mathrm{O}_{2}\left(\mathrm{NO}_{3}\right)_{3}\right]^{-}$. 
Acid leaching is the predominant process for uranium recovery from the uranium ores [29]. Sulphuric acid is used usually because of its low cost and availability. The $\mathrm{UO}_{2}{ }^{2+}$ and $\mathrm{SO}_{4}{ }^{2-}$ form monodentate and bidentate species in acidic aqueous solution [30]. At low concentration of sulfate and uranium, the predominated form is $\mathrm{UO}_{2} \mathrm{SO}_{4}$ with monodentate coordination structure of sulfate. The $\mathrm{UO}_{2}\left(\mathrm{SO}_{4}\right)_{2}{ }^{2-}$ species becomes dominant with increasing concentration of $\mathrm{SO}_{4}{ }^{2-}[30,31]$. In high concentration of $\mathrm{SO}_{4}{ }^{2-}$, the $\mathrm{UO}_{2}{ }^{2+}$ is coordinated by two bidentate sulfate groups [30]. It is worthy to notice that the complexes of $\mathrm{UO}_{2}{ }^{2+}$ with sulfate are stronger than with nitrate groups.

The study of the interaction between $\mathrm{UO}_{2}{ }^{2+}$ and $\mathrm{Cl}^{-}$ions showed that uranium(VI) exists only as $\mathrm{UO}_{2}{ }^{2+}$ and $\mathrm{UO}_{2} \mathrm{Cl}^{+}$ in the $\mathrm{NaCl}$ solution with concentration below $1.5 \mathrm{M}$ at low $\mathrm{pH}$. At higher brine concentration, the further complexation of uranium(VI) with $\mathrm{Cl}^{-}$takes place; so $\mathrm{UO}_{2} \mathrm{Cl}_{2}$ and $\mathrm{UO}_{2} \mathrm{Cl}_{3}{ }^{-}$species can be formed. At very high concentration of $\mathrm{NaCl}$, above $10 \mathrm{M}$, tetrachloro species $\mathrm{UO}_{2} \mathrm{Cl}_{4}{ }^{2-}$ can be also present [32].

Uranyl phosphates and uranyl arsenate minerals constitute about one-third of the approximately two hundreds known uranium minerals [33]. The speciation in the $\mathrm{UO}_{2}{ }^{2+}$ water-phosphate system was also studied [34]. In the $\mathrm{pH}$ range from 2 to 5 , two forms of species: $\mathrm{UO}_{2} \mathrm{H}_{2} \mathrm{PO}_{4}{ }^{+}$and neutral $\left(\mathrm{UO}_{2}\right)\left(\mathrm{HPO}_{4}\right)$ exist. At $\mathrm{pH}$ above 6.5 , negatively charged species $\mathrm{UO}_{2}\left(\mathrm{PO}_{4}\right)^{-}$is also formed.

Uranium forms also several complex species with arsenate ions in water solution. TRLFS (time-resolved laser fluorescence spectroscopy) showed the presence of $\mathrm{UO}_{2} \mathrm{H}_{2} \mathrm{AsO}_{4}{ }^{+}$, $\mathrm{UO}_{2}\left(\mathrm{HAsO}_{4}\right)$ and $\mathrm{UO}_{2}\left(\mathrm{H}_{2} \mathrm{AsO}_{4}\right)_{2}$ [35].

\section{Structures and Conformational Analysis of Calix[6]arenes}

The conformational flexibility of calix[6] arenes and presence of functional groups facilitates the binding of metal centers [36]. There are eight conformations of calix[6]arenes described in the literature [37]. They are called as distorted cone, compressed cone, pinched cone, double partial cone, winged, 1,2,3-alternate, 1,3,5-alternate, and distorted 1,2,3alternate.

Until now few crystal structures of $\mathrm{UO}_{2}{ }^{2+}$ with calix[6]arenes have been described. Calix[6]arenes similar to calix[8]arenes show smaller ability to form inclusion complexes than their lower homologies [38]. The first crystal structures of the uranium(VI) complex with calix[6]arene were reported by Thuéry et al. [39]. In the complex whose formula was $\left[\left(\mathrm{UO}_{2}{ }^{2+}\right)\left(\mathrm{H}_{2} \mathrm{~L}^{4-}\right)\right]_{2}\left(\mathrm{HNEt}_{3}{ }^{+}\right)_{2}\left(\mathrm{H}_{3} \mathrm{O}^{+}\right)_{2}$. $6 \mathrm{CH}_{3} \mathrm{CN}$, where $\mathrm{L}=$-tert-butylcalix[6]arene, each $\mathrm{UO}_{2}{ }^{2+}$ was bound to four oxygen atoms (two from each calixarene moiety). The mean value of $\mathrm{O}-\mathrm{U}-\mathrm{O}$ angle is $90^{\circ}$, suggesting that atom of uranium(VI) had octahedral centre of coordination. The conformation of the calix[6] arene was slightly distorted with respect to the usual pinched cone conformation of calix[6] arenes. The minus charge of the dimer was compensated by two protonated triethylamine molecules and two hydronium ions. Triethylamine molecules were outside of the calixarene in comparison to hydronium ions, which were inside the cavity defined by each calixarene. In the complex hydrogen, bonds were formed between the hydronium ions and two phenolic oxygen atoms nonbonded to the $\mathrm{UO}_{2}{ }^{2+}$ and with the nitrogen atom of one acetonitrile molecule, which was included in the hydrophobic cavity of the calixarene.

Later, Thuéry and Masci [40] studied the hetero(triand tetra-)nuclear complexes of $\mathrm{UO}_{2}{ }^{2+}$ and alkali metal $\left(\mathrm{Li}^{+}\right.$and $\mathrm{K}^{+}$) with $p$-tert-butylhexahomotrioxacalix[6] arene (L). The authors synthesized in the presence of lithium or potassium hydroxide the following complexes: $\left[\left(\mathrm{UO}_{2}\right)_{2} \mathrm{Li}(\mathrm{OH}) \mathrm{L}(\mathrm{py})\right]\left[\mathrm{Li}\left(\mathrm{H}_{2} \mathrm{O}\right)_{3}(\mathrm{py})\right] \cdot(\mathrm{Hpy}) \cdot \mathrm{H}_{2} \mathrm{O} \cdot 4.5$ py and $\left[\mathrm{UO}_{2} \mathrm{~K}\left(\mathrm{LH}_{3}\right)\left(\mathrm{H}_{2} \mathrm{O}\right)_{2}\right]_{2} \cdot 14$ py. The complex, which was obtained in the presence of lithium hydroxide, contained the trimetallic dianionic species, in which three cations were complexed in internal fashion. The two $\mathrm{UO}_{2}{ }^{2+}$ were bound to three phenoxide groups and the central hydroxide ion. The lithium ion was bound to two phenoxide groups and one other oxygen atom and the pyridine molecule. The geometry of coordination center of uranium(VI) could be described as distorted square bipyramidal environment.

The complex, which was obtained in the presence of potassium hydroxide, was built of an asymmetric unit, which contains $\left[\mathrm{UO}_{2} \mathrm{~K}\left(\mathrm{LH}_{3}\right)\left(\mathrm{H}_{2} \mathrm{O}\right)_{2}\right]_{2}$ heterobinuclear unit and pyridine solvent. $\mathrm{UO}_{2}{ }^{2+}$ was bound to three phenoxide groups and the potassium ion to two phenol groups and one of ether groups of $p$-tert-butylhexahomotrioxacalix[6] arene. To obtain the usual square bipyramidal geometry around the uranium atom, the $\mathrm{UO}_{2}{ }^{2+}$ completed its coordination sphere with a water molecule. The conformation of macrocycle could be described as a double partial cone. In comparison to the lithium complex, the potassium complex was dimeric.

The next crystal structure described in the literature was $\left[(\mathrm{HO})\left\{\mathrm{UO}_{2}\left(\text { calix }[6] \mathrm{H}_{4}\right)(\mathrm{dmso})\right\}_{3} \mathrm{H}\right] \cdot 11 \mathrm{MeCN} \cdot 6 \mathrm{H}_{2} \mathrm{O}$ synthesized by Delaigue et al. [41]. The conformation of calixarene ligand in this complex could be described as distorted cones. The complex was trinuclear. Uranium atoms were linked in their equatorial planes symmetrically by a "hydroxyl" oxygen atom, disposed on a crystallographic 3-axis in cubic space group $\mathrm{P} 2{ }_{1} 3$. The equatorial plane of uranium(VI) was of five coordinates; one of these sites was occupied by DMSO oxygen. Next two sites were occupied by adjacent phenoxyoxygen of calixarene ligand. In this case, $\mathrm{UO}_{2}{ }^{2+}$ was bound to the calixarene in an external manner.

There have been well-known structures of uranium(VI) complexes with calixarenes in a solid state, but not in a solution. The two spectroscopic methods described below may overcome the analytical problems, providing insight into the structure of complexes studied.

TRLFS is a very selective and sensitive method for actinide and lanthanide analysis because it can offer the spectral and temporal resolution together. This method provides information on lifetime and spectral characteristic of species, which can be used to obtain the number of different species and their spectral identity [42]. TRLFS has been widely used to investigate the speciation of 


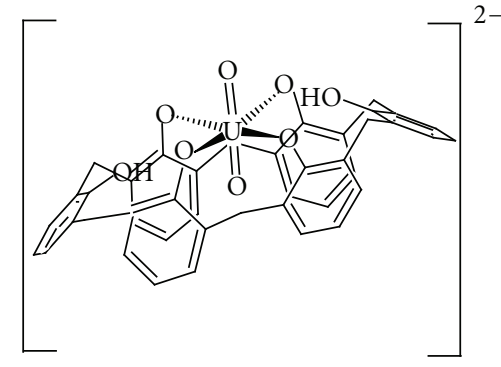

Endo

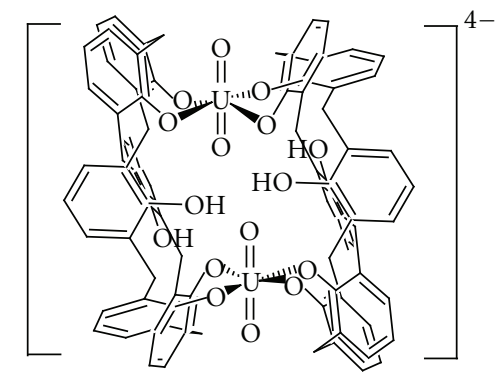

Exo

FIGURE 2: Endo- and exocavity binding in calix[6]arene.

the fluorescent metal ions, extracting quantitative and structural information from multiple TRLFS data measured as a function of chemical and physical parameters. The distinguishing ability of TRLFS relies on the fact that different chemical species of a fluorescent metal ion have different lifetimes of fluorescent and spectral shapes. The estimation of the number of different species, their concentrations, and their chemical or structural information from TRLFS data is a difficult task, due to overlapped spectra and similar fluorescence lifetimes. The development of statistical techniques such as two-way factor analysis (FA), evolving factor analysis (EFA) combined with multivariate curve resolution (MCR), or parallel factor analysis (PARAFAC) can overcome such difficulties [43]. TRLFS was used by Schmeide et al. [44] to study the complexation of uranium(VI) by calix[6]arenes in water and organic solvents.

EXAFS spectroscopy is a very useful method for structural studies of organometallic complexes in solution. This method can be used to probe a local structure providing information on the number of the adjacent atoms, their type, and their lengths from the absorbing atom. Using EXAFS measurements in the investigation of the complexes of calixarenes with metals was reported $[45,46]$.

It seems that the studies with spectroscopic techniques (EXAFS, TRLFS) could provide insight into the coordination models of novel calixarene complexes with uranium(VI).

\section{Kinetic Studies of the Complexation Uranium(VI) with Calixarenes}

Despite of very high selectivity $K_{\text {uranyl }} / K_{\mathrm{M}^{n+}}$ and remarkably large stability constants, calixarenes have a very slow binding rate with uranium(VI) [47]. This is because uranium(VI) is a linear guest cation. In order to permit $\mathrm{UO}_{2}{ }^{2+}$ to penetrate the calixarene ring first the exocomplex [16] is created and finally the endocomplex $[48,49]$ (Figure 2) is formed.

Nagasaki et al. [49] investigated the difference in the kinetics between the calixarene and noncyclic analog pentasodium 2,6-bis\{[2-hydroxy-3-(2-hydroxy-3-methyl5-sulfonate-(phenyl))methyl-5-sulfonate(phenyl)]methyl 4-sulfonate(phenol) (1) (Table 1). In case of the noncyclic ligand, the rate constants were greater than those for the cyclic ones. However, the examination of kinetic parameters revealed that rapid equilibration in case of noncyclic analogs was not only due to the fast forward complexation rate but also due to the more enhanced reverse decomplexation rate. The surprising effect was observed with pentasodium 31,32,33,34,35-pentahydroxycalix[5] arene-5,11,17,23,29-

pentasulfonate (2) that gave kinetic parameters much greater than those for hexasodium 37,38,39,40,41,42-hexahydroxycalix[6] arene-5,11,17,23,29,35-hexasulfonate (3). The authors reported that in contrast to calix[6]arene where at $\mathrm{pH} 6$ all six $\mathrm{OH}$ groups were dissociated, in calix[5] arene only four groups were dissociated [49]. The remained groups dissociated scarcely at $\mathrm{pH} 9$ to form the fully saturated pentacoordinate complex. In conclusion, the initial state and final state in the binding to $\mathrm{UO}_{2}{ }^{2+}$ were both destabilized, and the calix[5]arene ring was a priori distorted. In this connection, Nagasaki et al. [49] pointed out that calix[5]arenes and the noncyclic analog are better extraction agents for $\mathrm{UO}_{2}{ }^{2+}$ than calix[6]arenes. Later studies showed stable complexes of uranium(VI) with calix[6] arenes in exoconformation [39].

\section{Application of Calixarenes in Separation of Uranium(VI)}

5.1. Liquid-Liquid Extraction. The separation of metal ions from a solution and selective removal of particular cations are of interest in a variety of fields such as recovery of precious metal ions from the waste and hydrometallurgy. The separation methods that are often used include solvent extraction, chromatography, and membrane separation.

Two-phase solvent extraction of uranium(VI) with calixarene derivatives has been reported by several groups. This review concerns the uranophile properties of calix[5] arene and calix[6] arene derivatives.

Shinkai et al. [50] noticed that calix[5] arene and calix[6]arene had an ideal architecture for the design of uranophiles because the introduction of ligand groups into each benzene unit of these calixarenes exactly provided the required pseudoplanar penta- and hexacoordinate structures. They synthesized several water-soluble calixarene derivatives from calix $[n]$ arenes $(n=4,5,6)(4,2$, and 3 ) (Table 1$)$. They found that the 
TABLE 1: The structures of noncyclic analog $\mathbf{1}$ and calixarene derivatives 2-34.<smiles>Cc1cc(S(=O)(=O)O[Na])cc(Cc2cc(S(=O)(=O)O[Na])cc(Cc3cc([S+]([O])([O-])O[Na])cc(Cc4cc([S+]([O])([O-])O[Na])cc(Cc5cc([S+]([O])([O-])O[Na])cc(C)c5O)c4O)c3O)c2O)c1O</smiles>

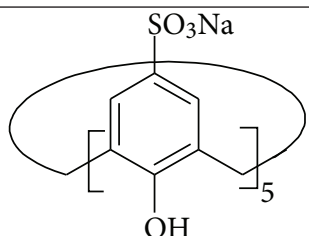

2

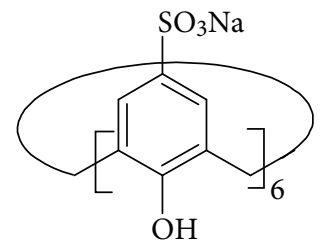

3
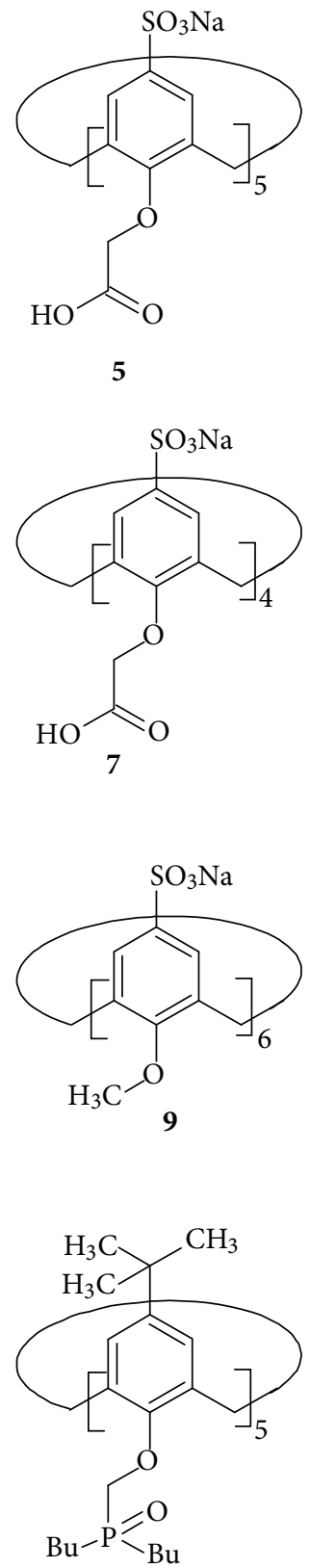
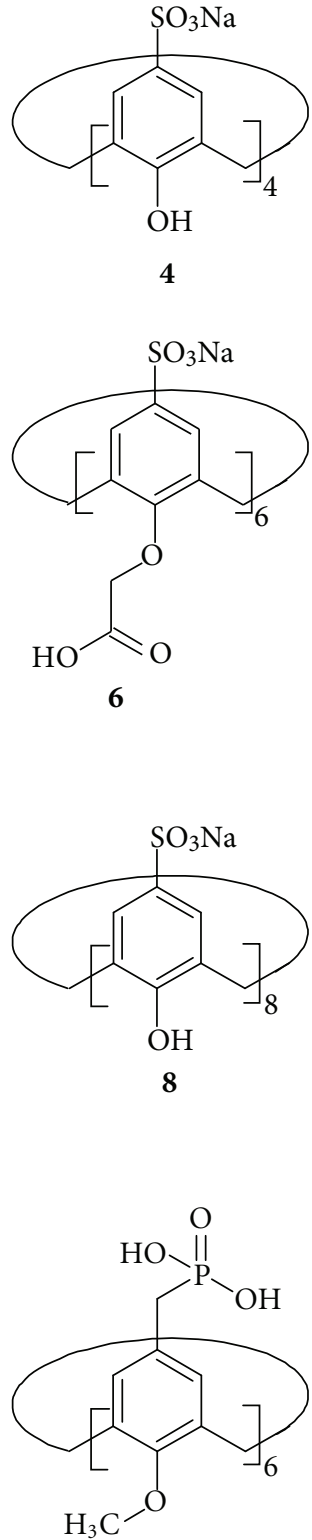

10

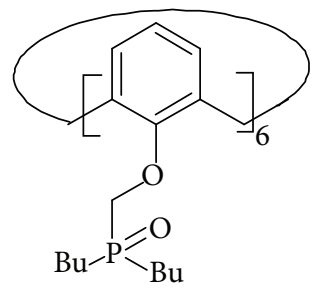

12 
TABLe 1: Continued.

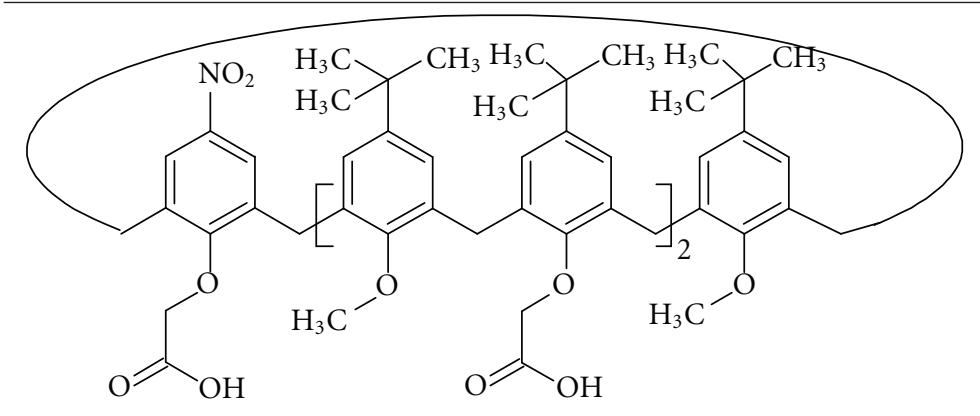

13

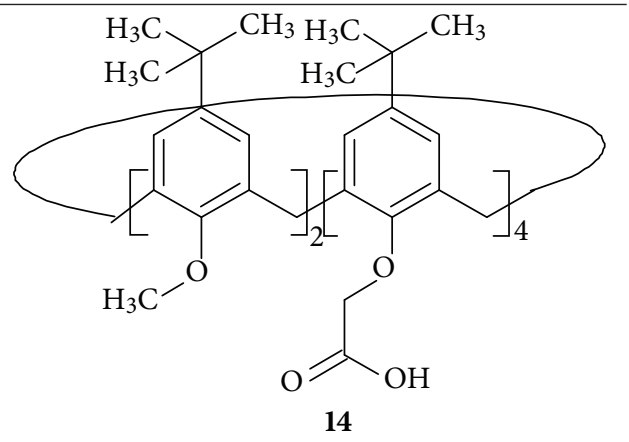

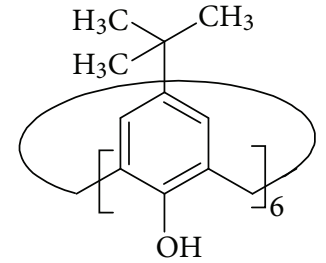

15

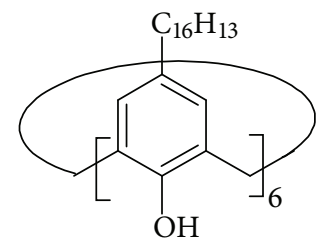

17<smiles>CCCCCc1cc(C(C)(C)C)cc(C)c1OCC(=O)NO</smiles>

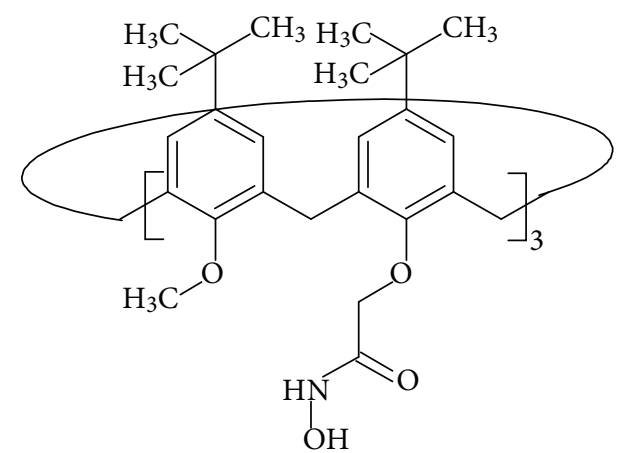

21

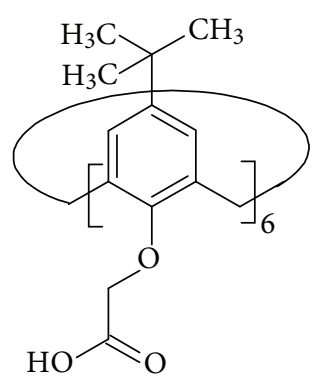

16<smiles>CCCCCCCCCc1cc(C)c(OCC(=O)O)c(Cl)c1</smiles>

18

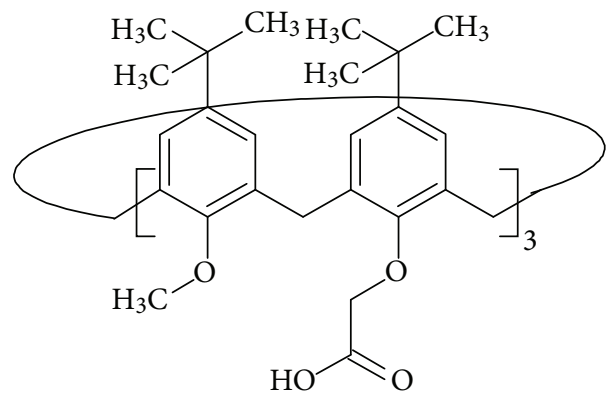

20

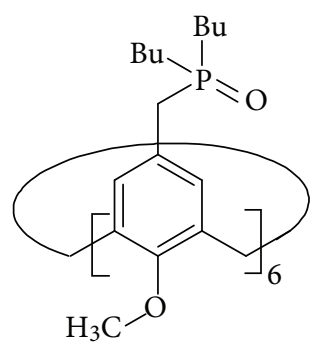

22 
TABLE 1: Continued.

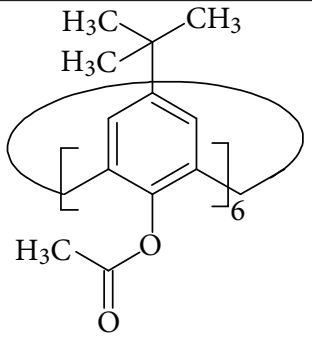

23

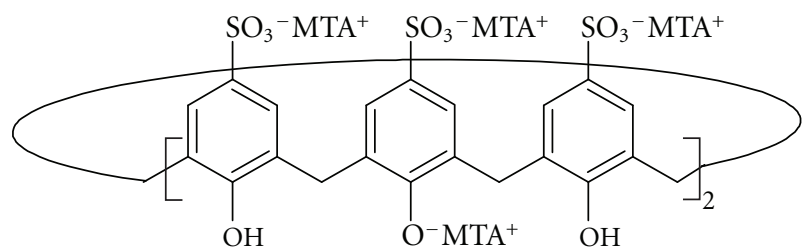

25

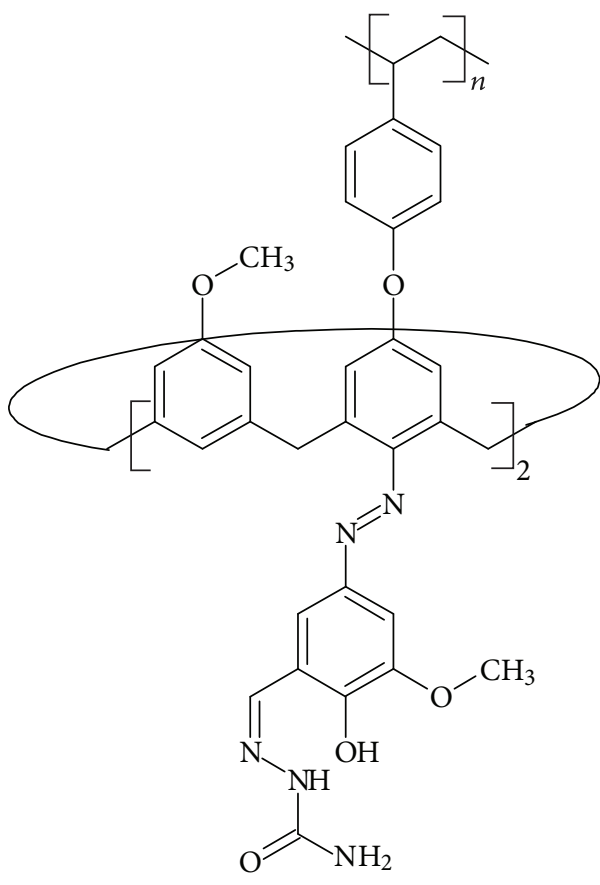

27

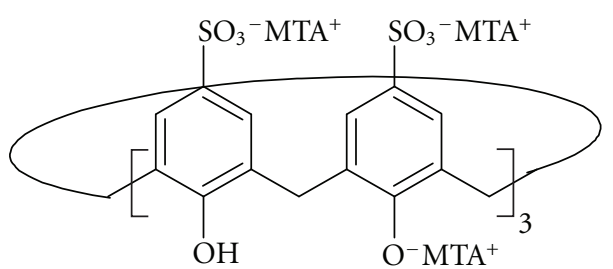

29

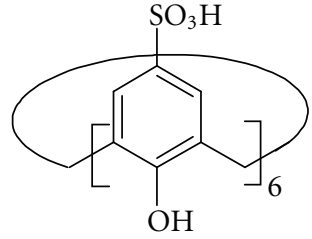

24

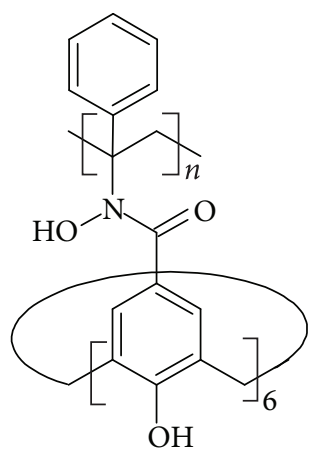

26
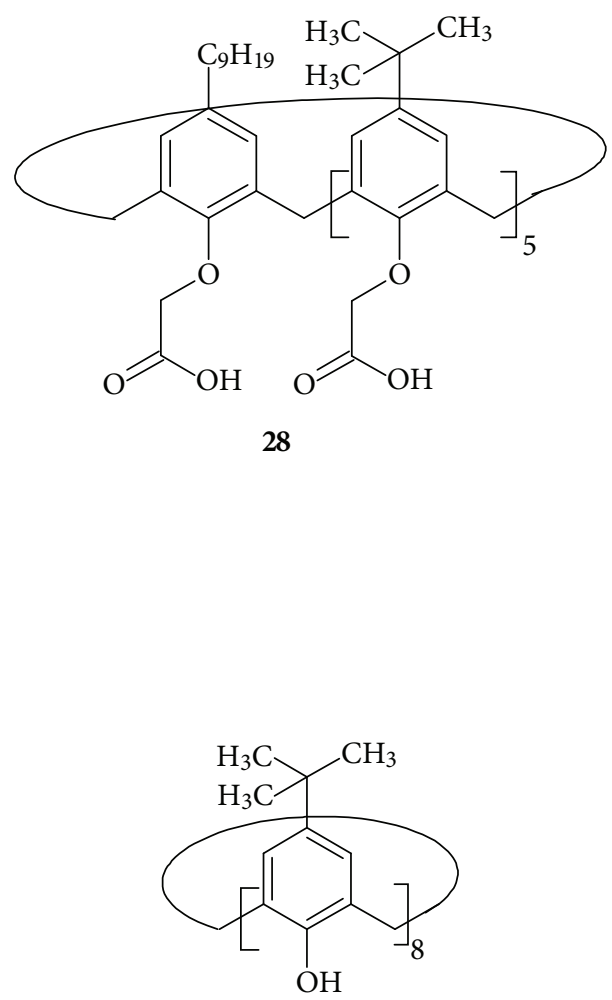

30 
TABle 1: Continued.

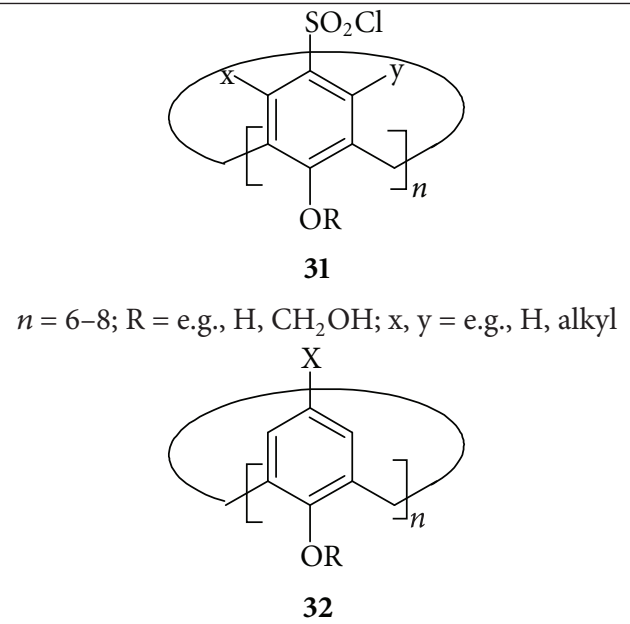

$n=2-8 ; \mathrm{R}=\mathrm{R}^{\prime}, \mathrm{CONH}(\mathrm{OH}) ; \mathrm{X}=\mathrm{H}, \mathrm{R}^{\prime \prime}$ or $\mathrm{SO}_{3} \mathrm{M} ; \mathrm{R}^{\prime}, \mathrm{R}^{\prime \prime}=$ lower hydrocarbon; $\mathrm{M}=\mathrm{H}$ or monovalent metal<smiles></smiles>

33<smiles>CCCOc1c(CCC)cc(C(C)(C)C)cc1Cc1cc(C(C)(C)C)cc(Cc2cc(C(C)(C)C)cc(Cc3cc(C(C)(C)C)cc(Cc4cc(C(C)(C)C)cc(C(C)(C)C)c4OCC(=O)NO)c3OCC(=O)NO)c2OCC(=O)NO)c1OCC(=O)NO</smiles>

$\mathrm{R}_{n}=\mathrm{H}$, halogen, acetyl, amino, phosphate, nitro, sulfate, carboxyl, carboxylic, thiocarboxylic, carbamate, thiocarbamate radical, alkyl C1-C60, alkenyl C2-C60, alkynyl C2-C60, cycloalkyl C13-C12, cycloalkyl with at least one ethylenic or acetylenic unsaturation, aryl, naphthyl, aryl(C1-C30 Alkyl), (C1-C30 Alkyl)Aryl, and $\mathrm{R}_{1}=\mathrm{R}_{2}=\mathrm{R}_{3}$ or $\mathrm{R}_{1}=\mathrm{R}_{2} \neq \mathrm{R}_{3}$ or $\mathrm{R}_{1} \neq \mathrm{R}_{2}=\mathrm{R}_{3}$ or $\mathrm{R}_{1} \neq \mathrm{R}_{3}=\mathrm{R}_{2}$ or $\mathrm{R}_{1} \neq \mathrm{R}_{3} \neq \mathrm{R}_{2}$.

$\mathrm{UO}_{2}{ }^{2+}$-complexes formed by pentasodium $31,32,33,34,35-$ penta(carboxymethoxy)calix[5] arene-5,11,17,23,29 pentasulfonate (5) and hexasodium 37,38,39,40,41,42-hexa(carboxymethoxy)calix[6] arene-5,11,17,23,29,35-hexasulfonate (6) had high stability (Table 2, entries 5 and 6) and furthermore, that these ligands showed also an unusual high selectivity for uranium(VI) (Table 3). It is worthy to notice that tetrasodium 25,26,27,28-tetrahydroxycalix[4] arene-5,11,17, 23-tetrasulfonate (4) and tetrasodium 25,26,27,28-tetra(car- boxymethoxy)calix[4] arene-5,11,17,23-tetrasulfonate were not efficient as complexing ligand of $\mathrm{UO}_{2}{ }^{2+}$ (Table 2, entries 4 and 7).

It is interesting that the stability constants for $\mathrm{UO}_{2}{ }^{2+}$ octasodium 50,51,52,53,54,55,56,57-octahydroxycalix[8]arene$5,11,17,23,29,35,41,47$-octasulfonate (8) (Table 2, entry 8) were comparable with those for calixarenes $\mathbf{2}$ and $\mathbf{3}$ (Table 2, entries 2 and 3). It is well known that the calix[8]arene ring is more flexible than the smaller calixarene rings $[55,56]$. 
TABLE 2: Stability constants $\left(K_{\text {uranyl }}{ }^{\mathrm{a}}\right)$ for the complexes of $\mathrm{UO}_{2}{ }^{2+}$ and calixarene derivatives at $25^{\circ} \mathrm{C}$.

\begin{tabular}{|c|c|c|c|c|c|}
\hline Entry & Extraction agent & $\log K_{\text {uranyl }}$ & Medium & $\mathrm{pH}$ & Reference \\
\hline 1 & $1^{b}$ & 17.7 & carbonate buffer & 10.4 & [49] \\
\hline 2 & 2 & 18.9 & $10^{-2} \mathrm{M}$ carbonate & 10.4 & {$[50]$} \\
\hline 3 & 3 & 19.2 & $10^{-2} \mathrm{M}$ carbonate & 10.4 & {$[50]$} \\
\hline 4 & 4 & 3.2 & $10^{-2} \mathrm{M}$ carbonate & 6.5 & {$[50]$} \\
\hline 5 & 5 & 18.4 & $10^{-2} \mathrm{M}$ carbonate & 10.4 & {$[50]$} \\
\hline 6 & 6 & 18.7 & $10^{-2} \mathrm{M}$ carbonate & 10.4 & {$[50]$} \\
\hline 7 & 7 & 3.1 & $10^{-2} \mathrm{M}$ carbonate & 6.5 & [50] \\
\hline 8 & 8 & $\begin{array}{l}18.7\left(\log K_{1}\right)^{\mathrm{c}} \\
18.1\left(\log K_{2}\right)^{\mathrm{c}}\end{array}$ & carbonate buffer & 10.4 & [49] \\
\hline 9 & 9 & 3.2 & $10^{-2} \mathrm{M}$ carbonate & 6.5 & {$[50]$} \\
\hline 10 & 10 & 16.3 & $10^{-2} \mathrm{M}$ carbonate & 10.4 & {$[51]$} \\
\hline 11 & 10 & 17.5 & $10^{-2} \mathrm{M}$ carbonate & 11.5 & {$[51]$} \\
\hline 12 & 11 & 2.7 & methanol & - & {$[52]$} \\
\hline 13 & 11 & 3.72 & acetonitrile & - & {$[52]$} \\
\hline 14 & 12 & 3.26 & methanol & - & {$[52]$} \\
\hline 15 & 12 & 3.6 & acetonitrile & - & {$[52]$} \\
\hline 16 & 13 & 9.93 & methanol & - & {$[53]$} \\
\hline 17 & 14 & 14.2 & methanol & - & [54] \\
\hline
\end{tabular}

${ }^{\mathrm{a}} K_{\text {uranyl }}=\left[\mathrm{UO}_{2}{ }^{2+} \cdot\right.$ Extraction agent complex $] /\left[\mathrm{UO}_{2}{ }^{2+}\right][$ Extraction agent $]$.

${ }^{\mathrm{b}}$ Noncyclic extractant $\mathbf{1}$.

${ }^{\mathrm{c}} K_{1}=\left[\mathrm{UO}_{2}{ }^{2+} \cdot \mathbf{8}\right.$ complex $] /\left[\mathrm{UO}_{2}{ }^{2+}\right][\mathbf{8}], K_{2}=\left[\left(\mathrm{UO}_{2}{ }^{2+}\right)_{2} \cdot \mathbf{8}\right.$ complex $] /\left[\mathrm{UO}_{2}{ }^{2+}\right]\left[\mathrm{UO}_{2}{ }^{2+} \cdot \mathbf{8}\right.$ complex $]$.

TABLE 3: Selectivity factor for $\mathrm{UO}_{2}{ }^{2+}\left(K_{\text {uranyl }} / K_{\mathrm{M}^{n+}}\right)$.

\begin{tabular}{|c|c|c|c|c|}
\hline Entry & Extraction agent & $\operatorname{Metal}\left(\mathrm{M}^{n+}\right)$ & $K_{\text {uranyl }} / K_{\mathrm{M}^{n+}}$ & Reference \\
\hline 1 & 3 & $\mathrm{Mg}^{2+}$ & $>10^{17}$ & [50] \\
\hline 2 & 3 & $\mathrm{Ni}^{2+}$ & $10^{17.0}$ & [50] \\
\hline 3 & 3 & $\mathrm{Zn}^{2+}$ & $10^{13.7}$ & [50] \\
\hline 4 & 3 & $\mathrm{Cu}^{2+}$ & $10^{10.6}$ & [50] \\
\hline 5 & 5 & $\mathrm{Mg}^{2+}$ & $>10^{17}$ & [50] \\
\hline 6 & 5 & $\mathrm{Ni}^{2+}$ & $10^{15.3}$ & [50] \\
\hline 7 & 5 & $\mathrm{Zn}^{2+}$ & $10^{13.1}$ & [50] \\
\hline 8 & 5 & $\mathrm{Cu}^{2+}$ & $10^{12.0}$ & [50] \\
\hline
\end{tabular}

Although the phenolic oxygens are not suitably arranged for coordination to $\mathrm{UO}_{2}{ }^{2+}$, the flexibility would allow and induce fit-type complexation with $\mathrm{UO}_{2}{ }^{2+}$. In contrast, $K_{\text {uranyl }}$ for noncyclic compound $\mathbf{1}$ (Table 2 , entry 1 ) was somewhat smaller than those values for cyclic extractant $\mathbf{2}$ and $\mathbf{3}$ (Table 2 , entries 2 and 3). The calix[4] arenes 4 and 7 could not form the stable uranyl complexes at $\mathrm{pH}$ range from 3 to 7 . In neutral-to-basic region, the calix[5] arene 2 and calix[6]arene 3 form with $\mathrm{UO}_{2}{ }^{2+}$ the stable $1: 1$ complexes, whereas the calix[8] arene $\mathbf{8}$ forms a $2: 1 \mathrm{UO}_{2}{ }^{2+}$ : complex. It is necessary to note that the complexation study was carried out in carbonate medium where the main species is $\mathrm{UO}_{2}\left(\mathrm{CO}_{3}\right)_{3}{ }^{4-}$. The carbonate ligands are replaced by calixarene ligands during the reaction $[49,50]$.

Hexasodium 37,38,39,40,41,42-hexamethoxycalix[6]arene-5,11,17,23,29,35-hexa-sulfonate (9) had a low stability constant (Table 2 , entry 9), on the contrary to the compound
6 (Table 2, entry 6) substituted with the carboxymethoxy group in the narrow rim. This indicates that carboxylate groups on the edge of the calixarene 6 are responsible for the $\mathrm{UO}_{2}{ }^{2+}$ binding.

The binding properties of phosphorylated calixarene derivatives bearing phosphonate or phosphine oxide groups either at the wide or narrow rim have been investigated towards $\mathrm{UO}_{2}{ }^{2+}[51,52]$. A high stability constant was observed for complex of $\mathrm{UO}_{2}{ }^{2+}$ with $37,38,39,40,41,42-$ hexamethoxy-5,11,17,23,29,35-hexakis(phosphonomethyl)calix[6] arene (10) (Table 2, entries 10 and 11). The complexes of 31,32,33,34,35-pentakis(dibutylphosphinylmethoxy)-5, 11,17,23,29-penta(p-tert-butyl)calix[5] arene (11) and 37,38, 39,40,41,42-hexakis(dibutylphosphinylmethoxy)calix[6]arene (12) with uranium(VI) had a lower stability (Table 2, entries 12-15). The complexation was carried out in two different solvents: methanol, whose properties are close to 
TABLE 4: Solvent extraction of $\mathrm{UO}_{2}{ }^{2+}$ at $30^{\circ} \mathrm{C}$.

\begin{tabular}{lccccc}
\hline Entry & Extraction agent & Ex\% & Organic phase & $\mathrm{pH}$ & Reference \\
\hline 1 & $\mathbf{1 5}$ & 4.6 & $o$-dichlorobenzene & 8.0 & {$[57]$} \\
2 & $\mathbf{1 5}$ & 0 & o-dichlorobenzene & 10.0 & {$[57]$} \\
3 & $\mathbf{1 6}$ & 100 & $o$-dichlorobenzene & 8.0 & {$[57]$} \\
4 & $\mathbf{1 6}$ & 93.3 & $o$-dichlorobenzene & 10.0 & {$[57]$} \\
5 & $\mathbf{1 7}$ & 22.5 & $o$-dichlorobenzene & 8.0 & {$[57]$} \\
6 & $\mathbf{1 7}$ & 0 & o-dichlorobenzene & 10.0 & {$[57]$} \\
7 & $\mathbf{1 8}$ & 100 & $o$-dichlorobenzene & 8.0 & {$[57]$} \\
8 & $\mathbf{1 8}$ & 90.0 & o-dichlorobenzene & 10.0 & {$[57]$} \\
9 & $\mathbf{1 5}$ & 100 & chloroform & 5.9 & {$[57]$} \\
10 & $\mathbf{1 9}$ & 100 & chloroform & 5.9 & {$[58]$} \\
\hline
\end{tabular}

those of water and acetonitrile, which is a medium-polarity solvent.

37,39,41-tris[(methoxycarbonyl)methoxy]-38,40,42-trimethoxy-35-nitro-5,11,17,23,29-penta-(tert-butyl)calix[6]arene (13) and 37,38,39,40-tetrakis(carboxymethoxy)-41,42dimethoxy-5,11,17,23,29,35-hexa(tert-butyl)calix[6]arene

(14) showed strong binding properties with $\mathrm{UO}_{2}{ }^{2+}$ in methanol (Table 2, entries 16 and 17) [53, 54].

It is worthy to notice that calix[5]arene 5, 11 and calix[6]arene $\mathbf{9}, \mathbf{1 2}$ formed a $1: 1 \mathrm{UO}_{2}{ }^{2+}$ : calixarene complex. However, this stoichiometry was not necessarily in agreement with that of the extracted complexes.

The selectivity of uranophiles can be evaluated by competitive binding with other metal cations. The results are presented in Table 3.

Shinkai et al. [57, 58] extended the concept of uranophile calixarenes to two-phase solvent extraction. 37,38,39, 40,41,42-hexahydroxy-5,11,17,23,29,35-hexa( $p$-tert-butyl)calix[6]arene (15) and 37,38,39,40,41,42-hexahydroxy$5,11,17,23,29,35$-hexahexylcalix[6]arene (17) showed very low extractability (Table 4, entries 1, 2, 5, and 6). On the other hand, hydrophobic hexacarboxylate derivatives of calix[6] arene: 37,38,39,40,41,42-hexakis(carboxymethoxy)5,11,17,23,29,35-hexa(p-tert-butyl)calix[6]arene (16), 37, 38,39,40,41,42-hexakis(carboxymethoxy)-5,11,17,23,29,35hexahexylcalix[6]arene (18), and 37,38,39,40,41,42hexakis( $N$-hydroxycarbamoylmethoxy)-5,11,17,23,29,35-

hexa( $p$-tert-butyl)calix[6]arene (19) were used to extract $\mathrm{UO}_{2}{ }^{2+}$ efficiently and selectively from water into organic media (Table 4).

Examination of Table 4 reveals that $\mathbf{1 6}$ and $\mathbf{1 8}$ (entries 3, 4, 7, and 8) exhibited excellent extractability (Ex\%). The slight decrease in extractability at higher $\mathrm{pH}$ was attributed to the hydrolysis of $\mathrm{UO}_{2}\left(\mathrm{CH}_{2} \mathrm{CO}_{2}\right)_{2}$. The low extractability for 15 and 17 was thus attributed to the $\mathrm{p} K_{a}$ of the $\mathrm{OH}$ groups, which is sensitive to the nature of parasubstituents. The values were lowered by electron-withdrawing groups for example, sulfonate group, so ligands such as $\mathbf{2}$ and $\mathbf{3}$ were able to associate well with $\mathrm{UO}_{2}{ }^{2+}$ at neutral to slightly basic $\mathrm{pH}$ [50]. In contrast, the $\mathrm{p} K_{a}$ values of $\mathbf{1 5}$ and $\mathbf{1 7}$ were too high to use them as uranophiles in this $\mathrm{pH}$ region. Also in contrast, as the $\mathrm{p} K_{a}$ values of 16 and 18 were scarcely affected by the nature of the parasubstituents, they behaved as excellent uranophiles at $\mathrm{pH} 8-10$ [57].

On the other hand, the compound 19, bearing hydroxamate groups on the lower rim, was an excellent uranophile even in the acidic $\mathrm{pH}$ region (Table 4 , entry 10). This $\mathrm{pH}$ dependence was correlated with the dissociation of the hydroxamic groups and binding to $\mathrm{UO}_{2}{ }^{2+}$.

It is worth noting that calixarene-based uranophiles from 15 to $18 \mathrm{did}$ not leak out into the aqueous phase. It was confirmed on the basis of spectrophotometric method [57]. The main difference between the homogeneous aqueous system and two-phase solvent-extraction system is that the species extracted into the organic phase must be "neutral" [59]. The above findings suggest, therefore, that calix[6]arene ${ }^{6-}$ bearing carboxylic or hydroxamic groups on the lower rim, for example, 16 and 19 formed a $1: 1$ complex with $\mathrm{UO}_{2}{ }^{2+}$, and the resultant complex $\left[(\mathbf{1 6}) \cdot \mathrm{UO}_{2}{ }^{2+}\right]^{4-}$ or $\left[(\mathbf{1 9}) \cdot \mathrm{UO}_{2}{ }^{2+}\right]^{4-}$ was neutralized by two $\mathrm{UO}_{2}{ }^{2+}$ adsorbed as countercations $[57,58]$.

In Table 5, the selectivity of hydrophobic calix[6]arenes is shown. Although calix[6]arenes 15, 16, and 19 could efficiently extract $\mathrm{UO}_{2}{ }^{2+}$ from aqueous solution to organic phase, the selectivity factors in two-phase solvent extraction were not so excellent as those obtained with $\mathbf{3}$ in aqueous system (Table 3). Much more excellent selectivity factors in solvent extraction of $\mathrm{UO}_{2}{ }^{2+}$ were observed when 37,39 , 41-tris(carboxymethoxy)-38,40,42-trimethoxy-5,11,17,23, 29,35-hexa(p-tert-butyl)calix[6]arene (20) was applied [60]. Extractability of 20 was a little inferior to those of $\mathbf{1 6}$ and $\mathbf{1 9}$ but reached nearly $100 \%$ at $\mathrm{pH} 7$.

37,39,41-tris( $N$-hydroxycarbamoylmethoxy)-38,40,42trimethoxy-5,11,17,23,29,35-hexa( $p$-tert-butyl)calix[6]arene (21) was shown as more efficient as the carboxylate one (20) for $\mathrm{UO}_{2}{ }^{2+}$ extraction [61]. The complex formed in the organic phase was $(\mathbf{2 1}) \cdot\left(\mathrm{UO}_{2}{ }^{2+}\right)$ with an apparent extraction constant equal to $7.1 \times 10^{-5} \mathrm{M}(I=0.04 \mathrm{M})$.

Further, the compound 21 has been found as an extractant molecule for selective separation of plutonium(IV) from uranium(VI) [62]. Both elements were selectively extracted depending on the aqueous phase $\mathrm{pH}$ (Table 6). At the first step, $93 \%$ of plutonium was extracted at $\mathrm{pH} 2$ by $\mathbf{2 1}$ 
TABle 5: Solvent extraction of $\mathrm{UO}_{2}{ }^{2+}$ in the presence of competing metal cations at $30^{\circ} \mathrm{C}$ and at $\mathrm{pH} 5.9$.

\begin{tabular}{|c|c|c|c|c|c|c|}
\hline Entry & Extraction agent & $\mathrm{M}^{n+}$ & {$\left[\mathrm{M}^{n+}\right] /\left[\mathrm{UO}_{2}{ }^{2+}\right]$} & $\mathrm{Ex} \%$ & Organic solvent & Reference \\
\hline 1 & 16 & $\mathrm{Mg}^{2+}$ & $5000^{a}$ & 72 & $o-\mathrm{Cl}_{2} \mathrm{C}_{6} \mathrm{H}_{4}{ }^{\mathrm{d}}$ & [57] \\
\hline 2 & 16/ $\mathrm{MTA}^{+} \mathrm{Cl}^{-\mathrm{c}}$ & $\mathrm{Mg}^{2+}$ & $5000^{\mathrm{a}}$ & 100 & $o-\mathrm{Cl}_{2} \mathrm{C}_{6} \mathrm{H}_{4}{ }^{\mathrm{d}}$ & [57] \\
\hline 3 & 16 & $\mathrm{Mg}^{2+}$ & $1000^{\mathrm{a}}$ & 100 & $\mathrm{CHCl}_{3}$ & {$[58]$} \\
\hline 4 & 19 & $\mathrm{Mg}^{2+}$ & $1000^{\mathrm{a}}$ & 100 & $\mathrm{CHCl}_{3}$ & {$[58]$} \\
\hline 5 & 20 & $\mathrm{Mg}^{2+}$ & $943.4^{\mathrm{b}}$ & 92 & $\mathrm{CHCl}_{3}$ & {$[60]$} \\
\hline 6 & 16 & $\mathrm{Ni}^{2+}$ & $12.5^{\mathrm{a}}$ & 93 & $o-\mathrm{Cl}_{2} \mathrm{C}_{6} \mathrm{H}_{4}^{\mathrm{d}}$ & [57] \\
\hline 7 & 16/ $\mathrm{MTA}^{+} \mathrm{Cl}^{-\mathrm{c}}$ & $\mathrm{Ni}^{2+}$ & $12.5^{\mathrm{a}}$ & 100 & $o-\mathrm{Cl}_{2} \mathrm{C}_{6} \mathrm{H}_{4}{ }^{\mathrm{d}}$ & [57] \\
\hline 8 & 16 & $\mathrm{Ni}^{2+}$ & $50^{\mathrm{a}}$ & 77 & $o-\mathrm{Cl}_{2} \mathrm{C}_{6} \mathrm{H}_{4}{ }^{\mathrm{d}}$ & [57] \\
\hline 9 & 16/ $\mathrm{MTA}^{+} \mathrm{Cl}^{-\mathrm{c}}$ & $\mathrm{Ni}^{2+}$ & $50^{\mathrm{a}}$ & 100 & $o-\mathrm{Cl}_{2} \mathrm{C}_{6} \mathrm{H}_{4}{ }^{\mathrm{d}}$ & [57] \\
\hline 10 & 19 & $\mathrm{Ni}^{2+}$ & $10^{\mathrm{a}}$ & 77 & $\mathrm{CHCl}_{3}$ & {$[58]$} \\
\hline 11 & 15 & $\mathrm{Ni}^{2+}$ & $10^{\mathrm{a}}$ & 98 & $\mathrm{CHCl}_{3}$ & {$[58]$} \\
\hline 12 & 20 & $\mathrm{Ni}^{2+}$ & $2.4^{\mathrm{b}}$ & 98 & $\mathrm{CHCl}_{3}$ & {$[60]$} \\
\hline 13 & 20 & $\mathrm{Ni}^{2+}$ & $9.4^{\mathrm{b}}$ & 98 & $\mathrm{CHCl}_{3}$ & {$[60]$} \\
\hline 14 & 16 & $\mathrm{Zn}^{2+}$ & $36.5^{\mathrm{a}}$ & 63 & $o-\mathrm{Cl}_{2} \mathrm{C}_{6} \mathrm{H}_{4}{ }^{\mathrm{d}}$ & [57] \\
\hline 15 & $16 / \mathrm{MTA}^{+} \mathrm{Cl}^{-\mathrm{c}}$ & $\mathrm{Zn}^{2+}$ & $36.5^{\mathrm{a}}$ & 90 & $o-\mathrm{Cl}_{2} \mathrm{C}_{6} \mathrm{H}_{4}{ }^{\mathrm{d}}$ & [57] \\
\hline 16 & 16 & $\mathrm{Zn}^{2+}$ & $60^{\mathrm{a}}$ & 51 & $o-\mathrm{Cl}_{2} \mathrm{C}_{6} \mathrm{H}_{4}{ }^{\mathrm{d}}$ & [57] \\
\hline 17 & 16/ $\mathrm{MTA}^{+} \mathrm{Cl}^{-\mathrm{c}}$ & $\mathrm{Zn}^{2+}$ & $60^{\mathrm{a}}$ & 84 & $o-\mathrm{Cl}_{2} \mathrm{C}_{6} \mathrm{H}_{4}{ }^{\mathrm{d}}$ & [57] \\
\hline 18 & 15 & $\mathrm{Zn}^{2+}$ & $12^{\mathrm{a}}$ & 51 & $\mathrm{CHCl}_{3}$ & {$[58]$} \\
\hline 19 & 19 & $\mathrm{Zn}^{2+}$ & $12^{\mathrm{a}}$ & 96 & $\mathrm{CHCl}_{3}$ & {$[58]$} \\
\hline 20 & 20 & $\mathrm{Zn}^{2+}$ & $6.9^{\mathrm{b}}$ & 98 & $\mathrm{CHCl}_{3}$ & {$[60]$} \\
\hline 21 & 19 & $\mathrm{Fe}^{3+}$ & $10^{\mathrm{a}}$ & 66 & $\mathrm{CHCl}_{3}$ & [58] \\
\hline 22 & 19 & $\mathrm{Fe}^{3+}$ & $1^{\mathrm{a}}$ & 100 & $\mathrm{CHCl}_{3}$ & {$[58]$} \\
\hline
\end{tabular}

${ }^{\mathrm{a}}\left[\mathrm{UO}_{2}\left(\mathrm{CH}_{3} \mathrm{CO}_{2}\right)_{2}\right]=0.020 \mathrm{mmol} \mathrm{dm}^{-3}$.

${ }^{\mathrm{b}}\left[\mathrm{K}_{4} \mathrm{UO}_{2}\left(\mathrm{CO}_{3}\right)_{3}\right]=0.106 \mathrm{mmol} \mathrm{dm}{ }^{-3}$.

${ }^{c} \mathrm{MTA}^{+} \mathrm{Cl}^{-}$methyltrioctylammonium chloride, $\left[\mathrm{MTA}^{+} \mathrm{Cl}^{-}\right]=1.0 \mathrm{mmol} \mathrm{dm}{ }^{-3}$.

${ }^{\mathrm{d}} \mathrm{o}$-dichlorobenzene.

TABLE 6: Successive extractions of $\mathrm{Pu}(\mathrm{IV})$ and $\mathrm{U}(\mathrm{VI})$ by 21 (extraction (\%) at each step).

\begin{tabular}{lccc}
\hline & $\begin{array}{c}\text { First step } \\
\text { pH 2.0 }\end{array}$ & $\begin{array}{c}\text { Second step } \\
\text { pH 5.0 }\end{array}$ & Reference \\
\hline $\mathrm{Pu}(\mathrm{IV})$ extraction $(\%)^{\mathrm{a}}$ & 93 & 8 & {$[62]$} \\
$\mathrm{U}(\mathrm{VI})$ extraction $(\%)^{\mathrm{a}}$ & 0 & 99 & {$[62]$} \\
\hline
\end{tabular}

${ }^{a}$ Organic solvent: 1,2,3,4-tetrahydronaphthalene.

without extraction of uranium. Then, increasing the $\mathrm{pH}$ of the aqueous phase to $\mathrm{pH} 5$ allowed the quantitative extraction of uranium(VI) by 21. However, it should be noted that at this $\mathrm{pH}$, more than $8 \%$ of the remaining plutonium(IV) was also extracted. It is necessary to note that the $\mathrm{Pu}(\mathrm{IV})$ is a spherical cation of $\mathrm{Pu}^{4+}$, not a trans-dioxo cation like $\mathrm{PuO}_{2}{ }^{2+}$ which is isostructural with the $\mathrm{UO}_{2}{ }^{2+}$.

The extraction mechanism of $\mathrm{UO}_{2}{ }^{2+}$ by calixarene 20 has been studied in a two-phase solvent-extraction system [63]. The competition between calix[6]arene and other complexing anions, such as phosphate or sulfate, has been investigated. The results showed that $\mathrm{UO}_{2}{ }^{2+}$ extraction was independent of the cation concentration, whatever the $\mathrm{pH}$ and the ionic strength were. The $\mathrm{UO}_{2}{ }^{2+}$-calixarene extraction constant was higher than that of the $\mathrm{UO}_{2}{ }^{2+}$-anion complexation.
Liquid-liquid extraction experiments of $\mathrm{UO}_{2}{ }^{2+}$ from nitric acid into $m$-nitrobenzotrifluoride $(m$-NBTF) with phosphorylated calix[5]arene and calix[6]arene derivatives were carried out [52]. The distribution coefficients $D$ obtained were shown to depend on the concentration of nitric acid in the aqueous phase (Table 7). The $D$ values decreased when the nitric acid concentration increased. This behavior was consistent with a competition between the metal ions and proton, as was seen with TOPO and phosphorylated extractant [52]. The values of the distribution coefficients determined for the calixarenes were even smaller than those of TOPO. Only the hexamer 37,38,39,40,41,42-hexamethoxy-5,11,17,23,29,35-hexakis(dibutyl-phosphinyl-methyl)-calix[6]arene (22) extracted $\mathrm{UO}_{2}{ }^{2+}$ much better than TOPO.

A synergistic effect was observed for the extraction of uranium(VI) when acetate solution was extracted with toluene containing p-tert-butylcalix[6]arene (15) or $37,38,39,40,41,42$-hexaacetoxy-5,11,17,23,29,35-hexa( $p$-tertbutyl)calix[6]arene (23) and thenoyltrifluoroacetone (HTTA) [64]. Also, the presence of alkali metal ions strongly influenced the extraction of $\mathrm{UO}_{2}{ }^{2+}$ by calixarene. This kind of extraction was advantageous for the separation of metal ions efficiently. Thus, whereas the calix[6]arene $\mathbf{1 5}$ and $\mathbf{2 3}$ studied display a very poor affinity for the $\mathrm{UO}_{2}{ }^{2+}$ (Table 8 , entries 1 and 2), these ligands behaved as very efficient 
TABLE 7: Extraction of $\mathrm{UO}_{2}{ }^{2+}$ from nitric acid solutions into $m$-NBTF by phosphorylated calixarenes. Distribution coefficients $D^{\mathrm{a}}$.

\begin{tabular}{lccccccc}
\hline \multirow{2}{*}{ Entry } & \multirow{2}{*}{ Extraction agent } & \multicolumn{3}{c}{ Nitric acid concentration (M) } & \multicolumn{2}{c}{ Reference } \\
\hline 1 & $\mathbf{1 1}$ & 0.1 & 0.3 & 1 & 3 & 0.15 & {$[52]$} \\
2 & $\mathbf{1 2}$ & 7.5 & 3.1 & 1.32 & 0.49 & 0.23 & 0.84 \\
3 & $\mathbf{2 2}$ & 21 & 16.8 & 12.1 & 8.6 & 4.0 & {$[52]$} \\
4 & TOPO $^{\mathrm{b}}$ & 8.3 & 5.9 & 1.23 & 0.19 & 0.09 & {$[52]$} \\
\hline
\end{tabular}

${ }^{\mathrm{a}} D$ : distribution coefficient, $D=\left[\mathrm{UO}_{2}{ }^{2+}\right]_{\mathrm{org}} /\left[\mathrm{UO}_{2}{ }^{2+}\right]_{\mathrm{aq}}$.

${ }^{\mathrm{b}}$ TOPO: trioctylphosphine oxide.

TABLE 8: The synergistic coefficients of $\mathrm{UO}_{2}{ }^{2+\mathrm{a}}$.

\begin{tabular}{|c|c|c|c|c|}
\hline Entry & System $(\mathrm{pH})$ & $D^{\mathrm{b}}$ & $\mathrm{SF}^{\mathrm{c}}$ & Reference \\
\hline 1 & $5 \times 10^{-3} \mathrm{M} 15(\mathrm{pH} 6.5)$ & 3.380 & - & {$[64]$} \\
\hline 2 & $5 \times 10^{-3} \mathrm{M} 23(\mathrm{pH} 5.0)$ & 0.035 & - & {$[64]$} \\
\hline 3 & $5 \times 10^{-3} \mathrm{M} 15+5 \times 10^{-3}$ M HTTA $(\mathrm{pH} 6.5)$ & 8.931 & 1.343 & {$[64]$} \\
\hline 4 & $5 \times 10^{-3}$ M $23+5 \times 10^{-3}$ M HTTA $(\mathrm{pH} 5.0)$ & 10.240 & 2.905 & {$[64]$} \\
\hline
\end{tabular}

${ }^{\mathrm{a}}\left[\mathrm{Na}^{+}\right]=0.04 \mathrm{M}$.

${ }^{\mathrm{b}} D$ : distribution coefficient, $D=\left[\mathrm{UO}_{2}{ }^{2+}\right]_{\mathrm{org}} /\left[\mathrm{UO}_{2}{ }^{2+}\right]_{\mathrm{aq}}$.

${ }^{c} \mathrm{SF}$ : synergistic factor, $\mathrm{SF}=D_{\text {syn }} /\left(D_{\mathrm{HTTA}}+D_{\mathrm{CALIX}}\right)$, where $D_{\text {syn }}$ is the distribution coefficient of the synergistic mixture.

extracting agents for this ion in the presence of HTTA (Table 8 , entries 3 and 4 ). The extraction was strongly dependent on $\mathrm{pH}$. The extraction decreased from $\mathrm{pH} 1$ to $\mathrm{pH} 3$ for acetatocalixarene/toluene/HTTA/sodium ion system began to increase from $\mathrm{pH} 4$, and it was saturated at around $\mathrm{pH} 5.0$ showing about $90 \%$ extractability. The synergistic effect was observed in the systems at $\mathrm{pH}>5$.

The strong ability of calixarene nanoemulsion to extract $\mathrm{UO}_{2}{ }^{2+}$ was found by Spagnul et al. $[65,66]$. They designed an oil-in water emulsion, taking advantage of the small droplet size offering a large contact surface with contaminated aqueous medium. The calixarene 20 nanoemulsion extracted up to $80 \%$ of uranium. It is important that the calixarene nanoemulsion effect was observed after a very short time of contact with uranium-contaminated solution. The calixarene nanoemulsion appeared to be a very promising system for uranium skin decontamination [65].

The reactivity of several calixarene derivatives as strong uranophiles could be utilized for sensitive electrochemical measurements of minor concentrations of $\mathrm{UO}_{2}{ }^{2+}$ in aqueous solution [67]. 37,38,39,40,41,42Hexahydroxy-5,11,17,23,29,35-hexasulfonic-calix[6]arene (24): cysteamine monolayer assembled on gold electrode was utilized for the determination of $\mathrm{UO}_{2}{ }^{2+}$ down to $1 \mathrm{ppm}$.

Jung et al. [68] studied the scavenging of $\mathrm{UO}_{2}{ }^{2+}$ using 4-sulfonic calix[6] arene 24 in the presence of goethite (iron oxyhydroxide). Goethite was selected because of its strong affinity to $\mathrm{UO}_{2}{ }^{2+}$ and its abundance in natural soil [69]. After adsorption of $\mathrm{UO}_{2}{ }^{2+}$ onto goethite, its extraction with the compound $\mathbf{2 4}$ in aqueous environment was studied. The results indicated that $\mathrm{UO}_{2}{ }^{2+}$ was almost completely extracted around $\mathrm{pH} 10.5$ when $\mathrm{U}(\mathrm{VI})$ : calixarene ratio was $1: 3$.
5.2. Extraction with Liquid Membranes. In order to selectively remove and recover metals from aqueous solution, the membrane-based processes are still being developed.

The selective transport of $\mathrm{UO}_{2}{ }^{2+}$ across the liquid membrane with hydrophobic derivative of calix[6] arene $\mathbf{1 6}$ as the carrier was studied by Shinkai et al. [57]. The authors examined the transport rate from $\mathrm{H}_{2} \mathrm{O}$ (source phase)organic solvent- $\mathrm{H}_{2} \mathrm{O}$ (receiving phase). They found that the rate determining step was the $\mathrm{UO}_{2}{ }^{2+}$ release from organic solvent to the receiving aqueous phase. The extent of $\mathrm{UO}_{2}{ }^{2+}$ transport was efficiently controlled by the changes in $\mathrm{pH}$ and temperatures.

Later Kondo et al. [70] investigated selective transport of $\mathrm{UO}_{2}{ }^{2+}$ through a bulk liquid membrane (BLM) containing hydrophobic ion associate of methyltrioctylammonium and hydroxycalix[6] arene- $p$-sulfonates (25) diluted in chloroform. The authors observed that the extraction rate of $\mathrm{UO}_{2}{ }^{2+}$ increased with increasing $\mathrm{pH}$ in the source phase as well as with increasing temperature in the temperature range $15-55^{\circ} \mathrm{C}$. This effect could be explained by increasing the concentration of dissociated carrier 25 . The developed system was not suitable for temperatures higher than $55^{\circ} \mathrm{C}$ since bubbles were generated in the membrane and sometimes the boiling solvent broke the layer structure of the interfaces of both aqueous phases with the membrane. The other ions, such as $\mathrm{Na}^{+}, \mathrm{K}^{+}, \mathrm{Mg}^{2+}, \mathrm{Ca}^{2+}, \mathrm{Sr}^{2+}, \mathrm{Ni}^{2+}, \mathrm{Cu}^{2+}, \mathrm{Zn}^{2+}, \mathrm{Fe}^{3+}$, $\mathrm{La}^{3+}, \mathrm{Eu}^{3+}$, and $\mathrm{Lu}^{3+}$, are not transported through the BLM, and therefore $\mathrm{UO}_{2}{ }^{2+}$ can be separated selectively.

A facilitated selective transport of $\mathrm{UO}_{2}{ }^{2+}$ across a BLM with the compound $\mathbf{1 5}$ in chloroform as ion carrier was studied by Ramkumar et al. [71] as well. With this system uranium(VI) with crown ethers as $\mathrm{UO}_{2}{ }^{2+}-18 \mathrm{C} 6$ was effectively 
separated from $\mathrm{Cu}^{2+}, \mathrm{Co}^{2+}, \mathrm{Ni}^{2+}$, and $\mathrm{Zn}^{2+}$. They confirmed that the transport of $\mathrm{UO}_{2}{ }^{2+}$ increased with the increase of the acidity of the receiving solution. The use of excess of crown ether $18 \mathrm{C} 6$ in proportion to calixarene $(100: 1)$ allowed decreasing $\mathrm{pH}$ in the receiving phase without loose of the extraction yield. It was caused by better solubility of uranyl ion in the membrane phase. The hydrophobic crown ether $18 \mathrm{C} 6$ plays a role in the absorption of uranyl ion into hydrophobic phase by bonding to coordination sphere of the metal ion. The authors [71] suggested that crown ether is involved in the secondary coordination sphere of the uranylcalixarene complex.

5.3. Ion Exchange and Chelating Resin. The separation of $\mathrm{Th}^{4+}, \mathrm{Ce}^{4+}$, and $\mathrm{UO}_{2}{ }^{2+}$ by polymer supported calix[6]arene hydroxamic acid 26 as a novel chelating resin was investigated by Trivedi et al. [72]. The novel resin was stable against light, air, water, and temperature up to $210^{\circ} \mathrm{C}$. With this system, $\mathrm{Th}^{4+}, \mathrm{Ce}^{4+}$, and $\mathrm{UO}_{2}{ }^{2+}$ were effectively separated by changing $\mathrm{pH}$ of sorption or phase elution. The yield of the recovery at pH 6.5 of the sorption was $(99.1 \pm 0.3) \%$ for $\mathrm{Th}^{4+}$ (in this $\mathrm{pH}$ region thorium ions were not sorbed), $(98.2 \pm 0.2) \%$ for $\mathrm{Ce}^{4+}$ with $0.1 \mathrm{M} \mathrm{HCl}$ as an eluent, $(97.6 \pm 0.2) \%$ for $\mathrm{UO}_{2}{ }^{2+}$ with $2 \mathrm{M} \mathrm{HCl}$ as an eluent.

A similar experiment was done by Jain et al. [73]. They studied the possibility of preconcentration of $\mathrm{UO}_{2}{ }^{2+}$ and $\mathrm{Th}^{4+}$ by using Merrifield chloromethylated resin anchored with calix[4] arene-o-vanilinsemicarbazone (27). The experiments showed that the $\mathrm{UO}_{2}{ }^{2+}$ can be separated from $\mathrm{Th}^{4+}$ and also from $\mathrm{La}^{3+}, \mathrm{Cu}^{2+}$, and $\mathrm{Pb}^{2+}$.

Schmeide et al. [74] studied the separation of $\mathrm{UO}_{2}{ }^{2+}$ from aqueous solution by mono- $p$-nonyl-penta- $p$-tert-butylcalix[6]arene hexacarboxylic acid (28) modified textiles. The best results were obtained for separation of $\mathrm{UO}_{2}{ }^{2+}$ at $\mathrm{pH} 7$ $(97.8 \%)$ and $\mathrm{pH} 5$ (94.9\%). They studied also the influence of other ions such as sodium, potassium, magnesium, and sulfate on the separation of $\mathrm{UO}_{2}{ }^{2+}$ by calixarene modified textiles. They found that neither at $\mathrm{pH} 5$ nor at $\mathrm{pH} 7 \mathrm{a}$ change of the separation yield of $\mathrm{UO}_{2}{ }^{2+}$ was observed. A different situation was observed in the case of calcium- and carbonate-rich waters. At $\mathrm{pH} 5$ there was no significant change, but at $\mathrm{pH} 7 \mathrm{UO}_{2}{ }^{2+}$ separation was reduced from $92 \%$ to $9 \%$. This was due to the formation of aqueous complex $\mathrm{Ca}_{2} \mathrm{UO}_{2}\left(\mathrm{CO}_{3}\right)_{3}$.

Koga et al. [75] used silica gel particles impregnated with ion associates containing sulfonatocalix[6]arene ions 29 and methyltrioctylammonium ions. They investigated adsorption properties for metals $\mathrm{Mg}^{2+}, \mathrm{Ca}^{2+}, \mathrm{Cu}^{2+}, \mathrm{Ni}^{2+}, \mathrm{Co}^{2+}, \mathrm{Sr}^{2+}$, $\mathrm{Ba}^{2+}$, and $\mathrm{UO}_{2}{ }^{2+}$ either at $\mathrm{pH} 5$ or 7 ; then these metals were eluted by dilute sulfuric acid. That complex-type adsorbents exhibited large and selective adsorptivities for $\mathrm{UO}_{2}{ }^{2+}$ and $\mathrm{Ba}^{2+}$. The best adsorptivity for $\mathrm{UO}_{2}{ }^{2+}$ was observed at $\mathrm{pH} 7$.

Ayata and Merdivan [76] showed that silica gel loaded with $p$-tert-butylcalix[8]arene (30) could be a potential agent for preconcentration of uranium(VI).

The best adsorption of uranium(VI) was observed in the $\mathrm{pH}$ range from 5 to 7 . At lower $\mathrm{pH}$, the adsorption was low because of the competition of hydronium ions with the $\mathrm{UO}_{2}{ }^{2+}$ for the adsorption sites. At higher $\mathrm{pH}$, uranium(VI) becomes hydrolysed to form oligomeric species (see Section 2).

\section{The Potential Industrial Application of Calix[6] arenes for Uranium(VI)}

The well-known high affinity of the calixarenes to $\mathrm{UO}_{2}{ }^{2+}$ make base for industrial use of them as reagents for the recovery of uranium from water solutions or removal from liquid waste generated from uranium mining and processing.

The patent from 1988 [77] concerns the use of calixarenes as adsorbent for $\mathrm{UO}_{2}{ }^{2+}$. This adsorbent consisted of polyethyleneimine, which had calixarene residue 31 bonded to the side chain by $\mathrm{SO}_{2} \mathrm{Cl}$ groups. It was characterized by an excellent affinity and selectivity.

In 1992, the patent for a calixarene derivative 32 [78] was published. This new compound has been useful as a host compound. Another ion or neutral compound could be bound in its cavity. Such compounds have shown excellent adsorption properties even at low $\mathrm{pH}$ which indicates that they can be used for adsorption and selective recovery of uranium(VI) from sea water or waste water, and so forth.

The invention described in American patent [79] was related to supported liquid membranes. The supporting materials contain the novel calixarenes with formula $\mathbf{3 3}$ and 34, which can be used for analytical measurements of uranium, americium, and plutonium. The main function of these materials is to extract the above-mentioned actinides from complex matrices, such as biological media.

\section{Conclusions}

Calix[6]arenes represent a family of macrocyclic molecules with a broad range of potential applications in chemical, analytical, and engineering materials fields. Low toxicity of these compounds makes them useful in applications of green chemistry and eco-friendly industrial processes.

The present paper demonstrated that calix[6]arenes act as very good uranophiles in different fields including separation processes (e.g., solvent extraction, membrane transport, and chromatographic process). They may be useful for extracting $\mathrm{UO}_{2}{ }^{2+}$ from solutions after leaching of uranium ores, sea water, radioactive waste, or natural soil. It was revealed that calixarenes bearing ligands including $\mathrm{P}=\mathrm{O}$ groups are more efficient than TBP (tributyl phosphate), TOPO (trioctylphosphine oxide), and CMPO (carbamoylphosphonate) for extraction of lanthanides and actinides. Application of such extracting agents enables the use of 10 to 100 times lower ligand concentrations necessary to reach an assumed extraction yield than with the other existing extractants. Extensive literature studies showed that extraction ability and selectivity of calixarene derivatives is closely related to their structural arrangement. Easy functionalization of these compounds enables simple engineering of the calixarene derivatives and preparation of the materials of good affinity to specific forms of uranium like $\mathrm{UO}_{2}{ }^{2+}$. 
The concept of uranophile calixarenes for liquid-liquid extraction and BLMs was studied with different calixarenes modified at the narrow and wide rims. The high effectiveness of calix[6]arenes in the process of separation of uranium(VI) from aqueous solutions was shown. It is necessary to notice that many factors, such as $\mathrm{pH}$, temperature, presence of other metal ions and counter ions, and the kind of solvent applied, affect the performance of the extraction of $\mathrm{UO}_{2}{ }^{2+}$. In most of the processes described above, the halogenated solvents were used. They are not acceptable in the industrial chemistry due to their cost and toxicity.

Ion exchange seems powerful technique, which can be used to separate uranium from other chemical substances. Similar to solvent extraction and BLMs transport, it uses the reversible reaction causing all $\mathrm{UO}_{2}{ }^{2+}$ to be reextracted. The advantages of ion exchange technique are lack of the organic solvent and the possibility of the control of the composition of the solutions by change of the eluent $\mathrm{pH}$.

\section{Acknowledgment}

The studies were supported by the Operative Programme Innovative Economy: Analysis of the Possibility of Uranium Supply from Domestic Resources (POIG 01.01.02-14-09409-00).

\section{References}

[1] B. Mokhtari, K. Pourabdollah, and N. Dalali, "Applications of nano-baskets of calixarenes in chromatography," Chromatographia, vol. 73, no. 9-10, pp. 829-847, 2011.

[2] D. T. Schühle, J. A. Peters, and J. Schatz, "Metal binding calixarenes with potential biometic and biomedical applications," Coordination Chemistry Reviews, vol. 255, pp. 2727-2745, 2011.

[3] B. Mokhtari, K. Pourabdollah, and N. Dallali, "A review of calixarene applications in nuclear industries," Journal of Radioanalytical and Nuclear Chemistry, vol. 287, no. 3, pp. 921-934, 2011.

[4] Uranium, "Resources, Production and Demand, A Joint Report by the OECD Nuclear Energy Agency and the International Atomic Energy Agency 2010," OECD, Paris, 2009.

[5] R. G. Denning, "Electronic structure and bonding in actinyl ions," Structure and Bonding, vol. 79, pp. 215-276, 1992.

[6] S. C. Bart and K. Meyer, "Highlights in uranium coordination chemistry," Structure and Bonding, vol. 127, pp. 119-176, 2008.

[7] I. Tabushi, Y. Kobuke, and T. Nishiya, "Macrocyclic hexaketone as a specific host of uranyl ion," Tetrahedron Letters, vol. 20, no. 37, pp. 3515-3518, 1979.

[8] I. Tabushi, Y. Kobuke, K. Ando, M. Kishimoto, and E. Ohara, "Macrocyclic hexacarboxylic acid. A highly selective host for uranyl ion," Journal of the American Chemical Society, vol. 102, no. 18, pp. 5947-5948, 1980.

[9] I. Tabushi, Y. Kobuke, and A. Yoshizawa, "Macrocyclic tridithiocarbamate as a specific uranophile," Journal of the American Chemical Society, vol. 106, no. 8, pp. 2481-2482, 1984.

[10] S. Shinkai, S. Mori, T. Tsubaki, T. Sone, and O. Manabe, "New water-soluble host molecules derived from calix[6]arene," Tetrahedron Letters, vol. 25, no. 46, pp. 5315-5318, 1984.
[11] C. D. Gutsche, B. Dhawan, M. Leonis, and D. Stewart, "p-tertButylcalix[6]arene," Organic Syntheses, vol. 68, pp. 238-242, 1990.

[12] W. Śliwa, "Calixarene complexes with transition metal, lanthanide and actinide ions," Croatica Chemica Acta, vol. 75, no. 1, pp. 131-153, 2002.

[13] Z. Asfari, V. Böhmer, J. Harrowfield, and J. Vicens, Calixarenes 2001, Kluwer Academic Publishers, Dordrecht, The Netherlands, 2001.

[14] R. V. Rodik, V. I. Boyko, and V. I. Kalchenko, "Calixarenes in bio-medical researches," Current Medicinal Chemistry, vol. 16, no. 13, pp. 1630-1655, 2009.

[15] G. Montavon, U. Repinc, C. Apostolidis, F. Bruchertseifer, K. Abbas, and A. Morgenstern, "Investigation of parasulfonatocalix[n]arenes $[\mathrm{n}=6,8]$ as potential chelates for 230U," Dalton Transactions, vol. 39, no. 5, pp. 1366-1374, 2010.

[16] M. Mariani, E. Macerata, M. Galletta et al., "Partitioning of minor actinides: effects of gamma irradiation on the extracting capabilities of a selected calixarene-based picolinamide ligand," Radiation Physics and Chemistry, vol. 76, no. 8-9, pp. 1285-1289, 2007.

[17] W. Hummel, G. Anderegg, L. Rao, I. Puigdomenech, and O. Tochiyama, "Chemical thermodynamics of compounds and complexes of U, Np, Pu, Am, Tc, Se, Ni and Zr with selected organic ligands," in Chemical Thermodynamics, vol. 9 of OECD Nuclear Energy Agency, Elselvier, Amsterdam, The Netherlands, 2005.

[18] R. Guillaumont, Th. Fanghänel, J. Fuger et al., "Update on the chemical thermodynamics of uranium, neptunium, plutonium, americium and technetium," in Chemical Thermodynamics, vol. 5 of OECD Nuclear Energy Agency, Elselvier, Amsterdam, The Netherlands, 2003.

[19] M. Bühl, R. Diss, and G. Wipff, "Coordination environment of aqueous uranyl(VI) ion," Journal of the American Chemical Society, vol. 127, no. 39, pp. 13506-13507, 2005.

[20] P. Nichols, E. J. Bylaska, G. K. Schenter, and W. de Jong, "Equatorial and apical solvent shells of the $\mathrm{UO}_{2}{ }^{2+}$ ion," Journal of Chemical Physics, vol. 128, no. 12, Article ID 124507, 2008.

[21] I. Farkas, I. Bányai, Z. Szabó, U. Wahlgren, and I. Grenthe, "Rates and mechanisms of water exchange of $\mathrm{UO}_{2}{ }^{2+}$ (aq) and $\mathrm{UO}_{2}{ }^{2+}$ (oxalate) $\mathrm{F}\left(\mathrm{H}_{2} \mathrm{O}\right)_{2}^{-}$: a variable-temperature $17 \mathrm{O}$ and $19 \mathrm{~F}$ NMR study," Inorganic Chemistry, vol. 39, no. 4, pp. 799-805, 2000.

[22] M. Åberg, D. Ferri, J. Glaser, and I. Grenthe, "Structure of the hydrated dioxouranium(VI) ion in aqueous solution. An X-ray diffraction and ${ }^{1} \mathrm{H}$ NMR study," Inorganic Chemistry, vol. 22, no. 26, pp. 3986-3989, 1983.

[23] L. Soderholm, S. Skanthakumar, and J. Neuefeind, "Determination of actinide speciation in solution using high-energy X-ray scattering," Analytical and Bioanalytical Chemistry, vol. 383, no. 1, pp. 48-55, 2005.

[24] C. Nguyen-Trung, D. A. Palmer, G. M. Begun, C. Peiffert, and R. E. Mesmer, "Aqueous uranyl complexes 1. Raman spectroscopic study of the hydrolysis of uranyl(VI) in solutions of trifluoromethanesulfonic acid and/or tetramethylammonium hydroxide at $25^{\circ} \mathrm{C}$ and $0.1 \mathrm{MPa}$, Journal of Solution Chemistry, vol. 29, no. 2, pp. 101-129, 2000.

[25] P. Zanonato, P. Di Bernardo, A. Bismondo, G. Liu, X. Chen, and L. Rao, "Hydrolysis of uranium(VI) at variable temperatures $\left(10-85^{\circ} \mathrm{C}\right)$," Journal of the American Chemical Society, vol. 126, no. 17, pp. 5515-5522, 2004. 
[26] H. Moll, T. Reich, and Z. Szabo, "The hydrolysis of dioxouranium(VI) investigated using EXAFS and ${ }^{17} \mathrm{O}-\mathrm{NMR}$, Radiochimica Acta, vol. 88, no. 7, pp. 411-415, 2000.

[27] C. Moulin, P. Decambox, V. Moulin, and J. G. Decaillon, "Uranium speciation in solution by time-resolved laser-induced fluorescence," Analytical Chemistry, vol. 67, no. 2, pp. 348-353, 1995.

[28] A. Ikeda-Ohno, C. Hennig, S. Tsushima, A. C. Scheinost, G. Bernhard, and T. Yaita, "Speciation and structural study of U(IV) and -(VI) in perchloric and nitric acid solutions," Inorganic Chemistry, vol. 48, no. 15, pp. 7201-7210, 2009.

[29] C. R. Edwards and A. J. Oliver, "Uranium processing: a review of current methods and technology," Journal of Management, vol. 52, no. 9, pp. 12-20, 2000.

[30] C. Hennig, A. Ikeda, K. Schmeide et al., "The relationship of monodentate and bidentate coordinated uranium(VI) sulfate in aqueous solution," Radiochimica Acta, vol. 96, no. 9-11, pp. 607-611, 2008

[31] D. Vopálka, K. Štamberg, A. Motl, and B. Drtinová, "The study of the speciation of uranyl-sulphate complexes by UV-Vis absorption spectra decomposition," Journal of Radioanalytical and Nuclear Chemistry, vol. 286, no. 3, pp. 681-686, 2010.

[32] D. T. Reed, S. B. Clark, and L. Rao, Actinide Speciation in High Ionic Strength Media, Kluwer Academic, Plenum Publishers, New York, NY, USA, 1999.

[33] L. R. Morss, N. M. Edelstein, J. Fuger, and J. Katz, Eds., The Chemistry of the Actinide and Transactinide Elements, vol. 1, Springer, Dordrecht, The Netherlands, 3rd edition, 2006.

[34] A. Sanding and J. Bruno, "The solubility of $\left(\mathrm{UO}_{2}\right)_{3}\left(\mathrm{PO}_{4}\right)_{2}$. $4 \mathrm{H}_{2} \mathrm{O}(\mathrm{s})$ and the formation of $\mathrm{U}(\mathrm{VI})$ phosphate complexes: their influence in uranium speciation in natural waters," Geochimica et Cosmochimica Acta, vol. 56, no. 12, pp. 4135-4145, 1992.

[35] G. Geipel, "Some aspects of actinide speciation by laser-induced spectroscopy," Coordination Chemistry Reviews, vol. 250, no. 78, pp. 844-854, 2006.

[36] A. J. Petrella and C. L. Raston, "Calixarenes as platforms for the construction of multimetallic complexes," Journal of Organometallic Chemistry, vol. 689, no. 24, pp. 4125-4136, 2004.

[37] C. D. Gutsche, Calixarenes: An Introduction, Royal Society of Chemistry, Cambridge, UK, 2nd edition, 2008.

[38] G. D. Andreetti, G. Calestani, F. Ugozzoli et al., "Solid state studies on p.t-butyl-calix[6] arene derivatives," Journal of Inclusion Phenomena, vol. 5, no. 1, pp. 123-126, 1987.

[39] P. Thuéry, M. Lance, and M. Nierlich, "Crystal structure of an uranyl/p-tert-butyl calix[6]arene dimer," Supramolecular Chemistry, vol. 7, no. 3, pp. 183-185, 1996.

[40] P. Thuéry and B. Masci, "Hetero(tri- and tetra-)nuclear complexes of uranyl and alkali metal $(\mathrm{Li}+, \mathrm{K}+)$ ions with p-tertbutylhexahomotrioxacalix[6] arene," Polyhedron, vol. 23, no. 4, pp. 649-654, 2004.

[41] X. Delaigue, C. D. Gutsche, J. M. Harrowfield et al., "Calixarene complexes of anion-bridged oligouranyl species," Supramolecular Chemistry, vol. 16, no. 8, pp. 603-609, 2004.

[42] M. Walter, T. Arnold, G. Geipel, A. Scheinost, and G. Bernhard, "An EXAFS and TRLFS investigation on uranium(VI) sorption to pristine and leached albite surfaces," Journal of Colloid and Interface Science, vol. 282, no. 2, pp. 293-305, 2005.

[43] T. Saito, H. Sao, K. Ishida et al., "Application of parallel factor analysis for time-resolved laser fluorescence spectroscopy: implication for metal speciation study," Environmental Science and Technology, vol. 44, no. 13, pp. 5055-5060, 2010.

[44] K. Schmeide, G. Geipel, and G. Bernhard, Abtrennung von Uran aus Waessriger Loesung durch Calix[6]arene Mittels fluessig-fluessig-Extraktion sowie Festphasen-Extraktion FZR414, November 2004.

[45] G. Izzet, Y. M. Frapart, T. Prangé, K. Provost, A. Michalowicz, and O. Reinaud, "X-ray diffraction and EXAFS studies of hydroxo- $\mathrm{Cu}(\mathrm{II})$ complexes based on a calix[6] arene-N3 ligand: evidence for a mononuclear-dinuclear equilibrium controlled by supramolecular features," Inorganic Chemistry, vol. 44, no. 26, pp. 9743-9751, 2005.

[46] J. X. Gao, J. C. Wang, C. L. Song et al., "Bis(crown6)calix[4]arene/Cs+ coordination chemistry in NPME solution," Journal of Solution Chemistry, vol. 35, no. 1, pp. 113-119, 2006.

[47] S. Shinkai, H. Koreishi, K. Ueda, and O. Manabe, "A new hexacarboxylate uranophile derived from calix[6]arene," Journal of the Chemical Society, Chemical Communications, no. 3, pp. 233-234, 1986.

[48] P. Guilbaud and G. Wipff, "Selective complexation of $\mathrm{UO}_{2}{ }^{2+}$ by the calix[6]arene ${ }^{6-}$ anion: structure and hydration studied by molecular dynamics simulations," Journal of Inclusion Phenomena and Molecular Recognition in Chemistry, vol. 16, no. 2, pp. 169-188, 1993.

[49] T. Nagasaki, K. Kawano, K. Araki, and S. Shinkai, "Kinetic studies of calixarene-based cyclic and non-cyclic superuranophiles," Journal of the Chemical Society, Perkin Transactions 2, no. 9, pp. 1325-1327, 1991.

[50] S. Shinkai, H. Koreishi, K. Ueda, T. Arimura, and O. Manabe, "Molecular design of calixarene-based uranophiles which exhibit remarkably high stability and selectivity," Journal of the American Chemical Society, vol. 109, no. 21, pp. 6371-6376, 1987.

[51] T. Nagasaki, T. Arimura, and S. Shinkai, "A new calix[6]arenebased uranophile with phosphonate groups as ligands," Bulletin of the Chemical Society of Japan, vol. 64, pp. 2575-2577, 1991.

[52] M. Karavan, F. Arnaud-Neu, V. Hubscher-Bruder, I. Smirnov, and V. Kalchenko, "Novel phosphorylated calixarenes for the recognition of f-elements," Journal of Inclusion Phenomena and Macrocyclic Chemistry, vol. 66, no. 1, pp. 113-123, 2010.

[53] R. Souane, V. Hubscher, Z. Asfari, F. Arnaud, and J. Vicens, "Synthesis of mono-, di-, and trinitro tricarboxymethyl calix[6]arenes for the complexation of uranium(VI)," Tetrahedron Letters, vol. 44, no. 50, pp. 9061-9064, 2003.

[54] R. Souane, V. Hubscher-Bruder, F. Arnaud-Neu, and J. Vicens, "Synthesis of a tetra carboxy methyl calix[6]arene for the complexation of uranium(VI). Comparison with related tri carboxy methyl derivatives," Journal of Nano \& Biotech, vol. 2, pp. 38-41, 2005.

[55] C. D. Gutsche, "Calixarenes," Accounts of Chemical Research, vol. 16, pp. 161-170, 1983.

[56] C. D. Gutsche, Syntesis ofMacrocyles: The Design of Selective Complexing Agents, John Wiley \& Sons, New York, NY, USA, 1987, Edited by: R. M. Izatt and J.J. Christensen.

[57] S. Shinkai, Y. Shiramama, H. Satoh et al., "Selective extraction and transport of $\mathrm{UO}_{2}{ }^{2+}$ with calixarene-based uranophiles," Journal of the Chemical Society, Perkin Transactions 2, no. 8, pp. 1167-1171, 1989.

[58] T. Nagasaki and S. Shinkai, "Synthesis and solvent extraction studies of novel calixarene-based uranophiles bearing 
hydroxamic groups," Journal of the Chemical Society, Perkin Transactions 2, no. 7, pp. 1063-1066, 1991.

[59] J. Rydberg, M. Cox, C. Musikas, and G. R. Choppin, Solvent Extraction Principles and Practiceed, Marcel Dekker, New York, NY, USA, 2nd edition, 2004.

[60] K. Araki, N. Hashimoto, H. Otsuka, T. Nagasaki, and S. Shinkai, "Molecular design of a calix[6] arene-based superuranophile with $\mathrm{C}_{3}$ symmetry. High $\mathrm{UO}_{2}{ }^{2+}$ selectivity in solvent extraction," Chemistry Letters, vol. 22, no. 5, pp. 829-832, 1993.

[61] B. Boulet, C. Bouvier-Capely, C. Cossonnet, and G. Cote, "Solvent extraction of U(VI) by calix[6]arenes," Solvent Extraction and Ion Exchange, vol. 24, no. 3, pp. 319-330, 2006.

[62] B. Boulet, C. Bouvier-Capely, G. Cote, L. Poriel, and C. Cossonnet, "Selective extraction of $\mathrm{Pu}(\mathrm{IV})$ by a calix[6] arene bearing hydroxamic groups. Application to bioassays," Journal of Alloys and Compounds, vol. 444-445, pp. 526-528, 2007.

[63] C. Dinse, N. Baglan, C. Cossonnet, J. F. Le Du, Z. Asfari, and J. Vicens, "Solvent extraction of U(VI) from media containing competing anions and metal cations by a calix[6]arene bearing carboxy groups," Journal of Alloys and Compounds, vol. 271-273, pp. 778-781, 1998.

[64] M. C. F. C. Felinto and V. F. Almeida, "Solvent extraction separation of uranium (VI) with acetatecalix[n]arene and $\beta$ diketone (HTTA)," Journal of Alloys and Compounds, vol. 303304, pp. 524-528, 2000.

[65] A. Spagnul, C. Bouvier-Capely, G. Phan, F. Rebière, and E. Fattal, "Calixarene-entrapped nanoemulsion for uranium extraction from contaminated solutions," Journal of Pharmaceutical Sciences, vol. 99, no. 3, pp. 1375-1383, 2010.

[66] A. Spagnul, C. Bouvier-Capely, M. Adam, G. Phan, F. Rebière, and E. Fattal, "Quick and efficient extraction of uranium from a contaminated solution by a calixarene nanoemulsion," International Journal of Pharmaceutics, vol. 398, no. 1-2, pp. 179-184, 2010.

[67] A. Becker, H. Tobias, Z. Porat, and D. Mandler, "Detection of uranium(VI) in aqueous solution by a calix[6] arene modified electrode," Journal of Electroanalytical Chemistry, vol. 621, no. 2, pp. 214-221, 2008.

[68] J. Jung, Y. H. Cho, and P. S. Hahn, "Scavenging of $\mathrm{UO}_{2}{ }^{2+}$ using 4 -sulfonic calix[6]arene in the presence of goethite," Journal of Radioanalytical and Nuclear Chemistry, vol. 242, no. 3, pp. 635-639, 1999.

[69] H. M. Steele, K. Wright, and I. H. Hillier, "Modelling the adsorption of uranyl on the surface of geothite," Geochimica et Cosmochimica Acta, vol. 66, no. 8, pp. 1305-1310, 2002.

[70] H. Kondo, M. Nishida, and I. Yoshida, "Highly selective transport of a uranyl ion through a liquid membrane containing a lipophilic ion-associate of methyltrioctylammonium and hydroxycalix[n]arene-p-sulfonates $(n=6,8)$ as metal carriers," Analytical Sciences, vol. 18, no. 2, pp. 113-118, 2002.

[71] J. Ramkumar, S. K. Nayak, and B. Maiti, “Transport of uranyl ion across a bulk liquid membrane using calixarene and synergistic agents as carriers," Journal of Membrane Science, vol. 196, no. 2, pp. 203-210, 2002.

[72] U. V. Trivedi, S. K. Menon, and Y. K. Agrawal, "Polymer supported calix[6]arene hydroxamic acid, a novel chelating resin," Reactive and Functional Polymers, vol. 50, no. 3, pp. 205-216, 2002.

[73] V. K. Jain, R. A. Pandya, S. G. Pillai, and P. S. Shrivastav, "Simultaneous preconcentration of uranium(VI) and thorium(IV) from aqueous solutions using a chelating calix[4]arene anchored chloromethylated polystyrene solid phase," Talanta, vol. 70, no. 2, pp. 257-266, 2006.

[74] K. Schmeide, K. H. Heise, G. Bernhard, D. Keil, K. Jansen, and D. Praschak, "Uranium(VI) separation from aqueous solution by calix[6]arene modified textiles," Journal of Radioanalytical and Nuclear Chemistry, vol. 261, no. 1, pp. 61-67, 2004.

[75] M. Koga, S. Seki, M. Nishida, and I. Yoshida, "Selective metalion adsorptivities of silica gel particles impregnated with $\mathrm{p}$ sulfonatocalix[n]arenes ( $\mathrm{n}=6$ and 8 ) having fixed steric structure," Bunseki Kagaku, vol. 55, no. 2, pp. 101-107, 2006 (Japanese).

[76] S. Ayata and M. Merdivan, "P-tert-Butylcalix[8]arene loaded silica gel for preconcentration of uranium(VI) via solid phase extraction," Journal of Radioanalytical and Nuclear Chemistry, vol. 283, no. 3, pp. 603-607, 2010.

[77] Y. Kondo, T. Yamamoto, O. Manabe, and S. Shinkai, "Japanese Patent no. 63277240 (A)," Uranium adsorbent, 1988.

[78] S. Shinaki, T. Arimura, T. Nagasaki, and T. Matsuda, "Japanese Patent no. 4091070 (A)," Calixarene derivative, 1992.

[79] R. Duval and C. Cossonet, C. Bouvier-Capely American Patent no. 20090095681, p-tert-butylcalix[6] arenes with triacidic functions at 2. 4 and 6, supported liquid membranes and support materials comprising the same and use thereof, 2009. 

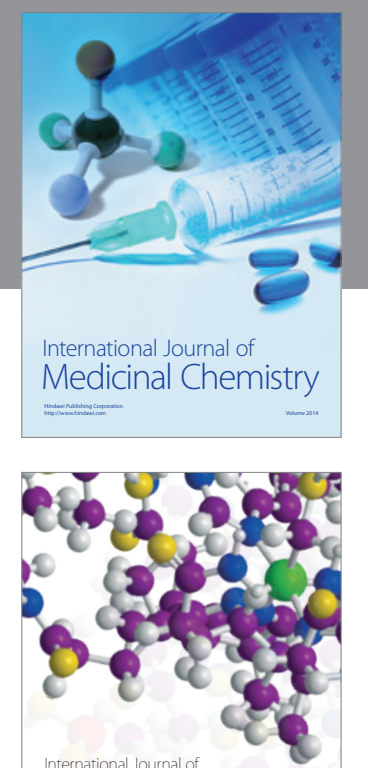

\section{Carbohydrate} Chemistry

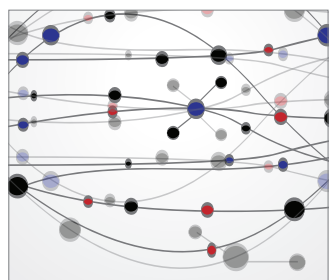

The Scientific World Journal
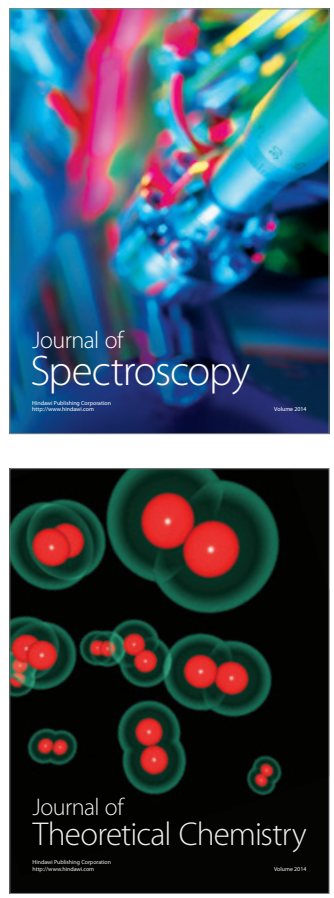
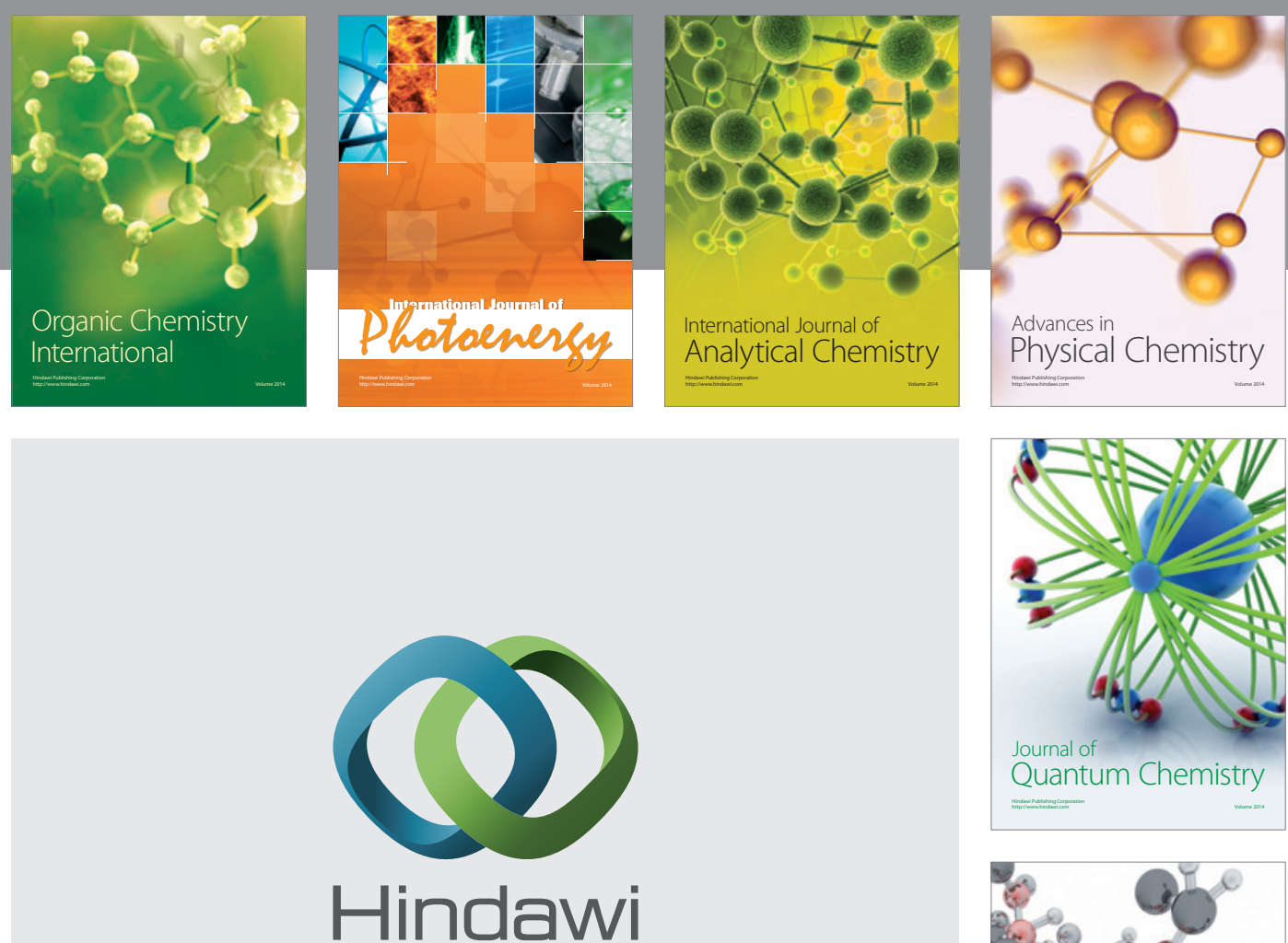

Submit your manuscripts at

http://www.hindawi.com

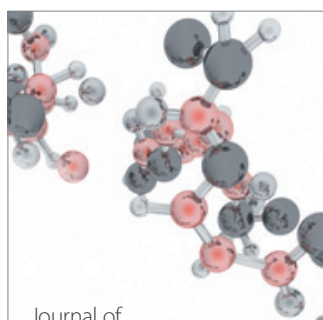

Analytical Methods

in Chemistry

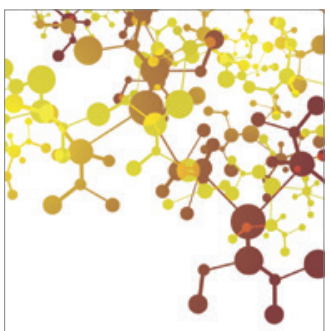

Journal of

Applied Chemistry

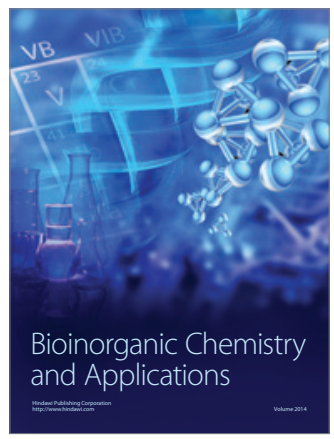

Inorganic Chemistry
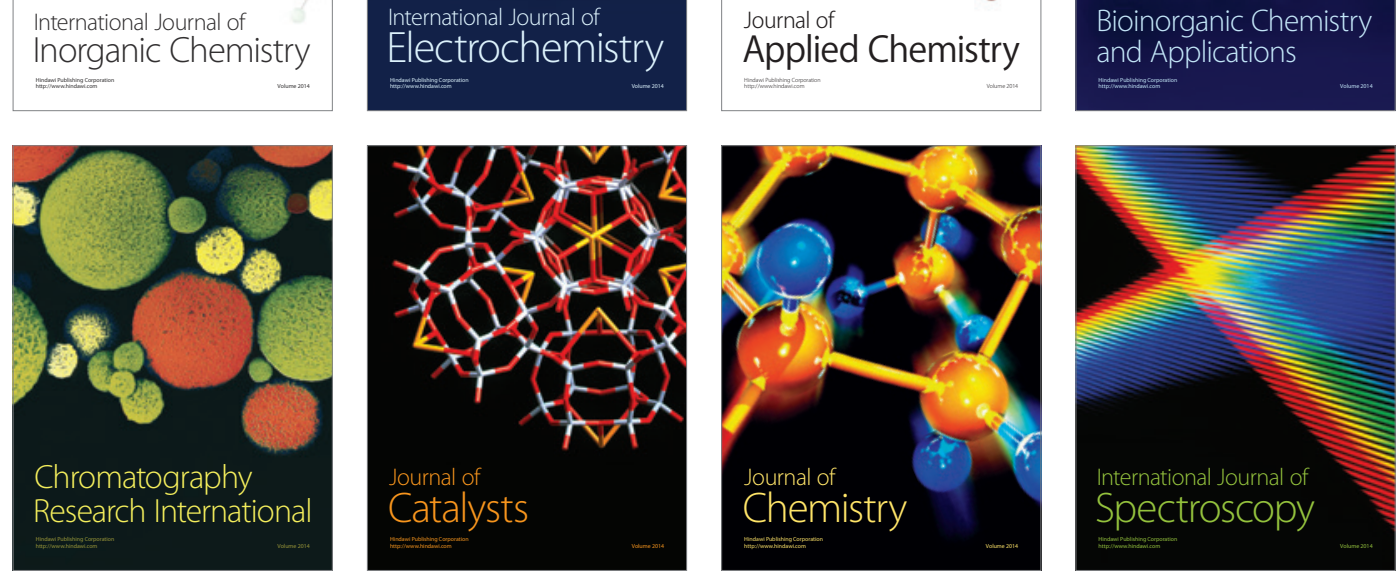